\title{
G Research Square \\ Pollutant emissions in livestock buildings: influence of indoor environment, rearing systems, and manure management
}

Leonardo de Brito Andrade ( $\sim$ leonardo.andrade@ufsc.br)

Federal University of Santa Catarina: Universidade Federal de Santa Catarina https://orcid.org/00000003-0304-8838

\section{César Martín-Gómez}

University of Navarra: Universidad de Navarra

Amaia Zuazua-Ros

University of Navarra: Universidad de Navarra

Arturo H. Ariño

University of Navarra: Universidad de Navarra

\section{Research Article}

Keywords: Pollutant Emissions, Livestock buildings, Animal buildings, Indoor Air Quality, Air pollution

Posted Date: May 23rd, 2022

DOI: https://doi.org/10.21203/rs.3.rs-1156152/v2

License: (9) This work is licensed under a Creative Commons Attribution 4.0 International License. Read Full License

Version of Record: A version of this preprint was published at Journal of Veterinary Health Science on July 28th, 2022. See the published version at https://doi.org/10.33140/JVHS.03.03.03. 


\section{Abstract}

The issue of air pollutants from livestock buildings is prevalent in the literature. Because they and their emissions impact both animal production and livestock building users as well as the outdoor environment. This paper aims to compile and review data available in the scientific literature on the types of pollutants for a better understanding of their generation form, their distribution according to the kind of animal, and the main factors affecting their generation and concentration, i.e., the rearing system, the indoor microclimate, and the manure management.

The elevated generation of pollutants in animal buildings is tied to the dense occupancy in this industrial activity. The indoor air quality is defined according to the type of livestock in animal housing, considering its welfare needs, and the types and concentrations of pollutants generated as a function of the family of animal and the management used in production. The main gases generated are $\mathrm{CH}_{4}, \mathrm{CO}_{2}, \mathrm{H}_{2} \mathrm{~S}, \mathrm{NH}_{3}, \mathrm{~N}_{2} \mathrm{O}$, in addition to particulate matter and airborne microorganisms such as fungi and bacteria that very negatively affect the health of animals and users of the animal buildings.

Furthermore, knowledge about the main contaminants generated, the form of generation, their origin, their concentrations, and their distribution throughout the shed is essential to achieve a permanent and adequate indoor air quality and, with that, a high-quality product that will lead to high production yield without neglecting animal welfare.

\section{Introduction}

FAO data (FAO 2020) show that from 1961 to 2018, the world population increased by $147 \%$ while the total meat production (all types) increased by $380 \%$. Another fact is that livestock production represents $50 \%$ of the total agricultural product and supports many developing countries (Herrero et al. 2016; FAO 2017).

The animal production figures are a direct result of human consumption. As of 2019, chickens, pigs, goats and sheep, and cattle and buffaloes were reared for meat production amounting to $27.5 \times 10^{9}$ (billion) live animals (of which chicken were about 23 billion), while almost 234 million cows were used for milk production. In contrast, in the egg production sector, there were 7.5 billion laying hen (FAO 2020). Figure 1 illustrates the development of animal production and the corresponding growth of greenhouse gas emissions in the livestock industry.

A significant intensification in livestock farming production has occurred because of the increase in both livestock buildings and indoor animal crowding in search for higher productivity. Other factors that enable the production growth can also be cited, such as using feed of higher nutritional value, improvement of pharmaceuticals, routine vaccination, and improvement of the infrastructure and feed efficiencies (Leip et al. 2015). 
Collectively known as Animal Feeding Operations (AFO) and occurring within facilities where animals are concentrated or confined, these factors contributed to increasing animal production (Ramankutty et al. 2018). Currently, such facilities represent the most extensive, worldwide method for industrial-scale livestock production (Mallin et al. 2015).

The impact of livestock production on surroundings is also relevant, causing effects on air, water, soil, biodiversity, and climate change, resulting in increased local and global environmental concerns (Leip et al. 2015). Therefore, reducing the pollutant emissions from management in animal buildings, emphasizing Indoor Air Quality (IAQ) improvement for the AFO, can now be considered the main research topic (Ni 2015).

Massive efforts have been invested in the basic research to achieve new conceptions on air pollution. Several research projects have focused on identifying, quantifying, characterizing, and modeling air pollutant emissions in animal buildings through improving sampling and monitoring devices and developing mitigation methods. Results have yielded practical knowledge about what determines IAQ in different types of livestock production (Ni 2015).

Some introductory examples of research that lead to this knowledge can be considered. (Zhao et al. 2015) monitored the environment of three different laying-hen housing systems: conventional cage, enriched colony, and typical aviary, and concluded that the IAQ was similar in conventional cage and enriched colony, both with ammonia and particulate matter concentrations bellow the typical aviary. On the other hand, (Chai et al. 2018) found that while cage-free housing better agrees with natural behaviors of hens (foraging, dustbathing, wing-flapping, etc.), IAQ was lower than in the conventional system.

(Ni et al. 2012a) tested two types of laying-hen houses (high-rise and manure-belt) and verified the influence of the house design resulting in worse IAQ in a high-rise as compared to manure-belt, where a strong correlation was observed between IAQ and climate parameters (temperature and airflow rate) and animal conditions, influencing the results.

Different building materials also exposed to potential influence in IAQ. (Wang et al. 2011) found that selecting floor material became critical for IAQ. They compared two commonly-used systems in pig houses: fully slatted floor and deep fermented litter and concluded that the IAQ was worse in the case of the slatted floor.

This article aims to compile and discuss information regarding the influence of the indoor microclimate, the rearing system, and the management of animal manure on the Indoor Air Quality in livestock buildings, focusing on atmospheric pollutant emissions from intensive animal production (Table 1). 
Table 1

Key aspects of review.

\begin{tabular}{|ll|}
\hline Key aspects & Details \\
\hline Environment conditions & $\begin{array}{l}\text { Influence of temperature, relative humidity, and airflow. } \\
\text { Diurnal patterns. } \\
\text { Influence of seasons. }\end{array}$ \\
\hline Rearing system & $\begin{array}{l}\text { Rearing system applied. } \\
\text { Bedding and building materials. }\end{array}$ \\
\hline Manure management & $\begin{array}{l}\text { Characteristics (chemical, physical, size/magnitude). } \\
\text { Management/movement/storage inside the building. }\end{array}$ \\
\hline
\end{tabular}

\section{Methodology For Searching And Selecting Scientific Papers}

We searched articles in the Scopus ${ }^{\circledR}$ database using the following keywords: "pollutant emissions", "animal buildings", "indoor air quality", "livestock animals", and "GHG emissions", without restrictions for year of publication or type of article. Therefore, publications such as books, periodicals, conference reports, technical reports, regulations, and technical guidelines were initially included in the result sets. Articles in the first result (Round 1) were then examined and their cited literature was recursively checked (up to six additional rounds) for additional relevant articles, which were then directly retrieved and examined (Fig. 2). A total of 295 technical or scientific documents were listed, although after detailed individual examination not all ended up yielding data relevant to this review. Most documents turned out to be regular scientific research papers, including a sizable number of review and discussion papers, but very relevant data emerged also from other types of documents such as inventories, databases, and technical reports.

Figure 3 shows the non-exclusive breakdown of retrieved documents according to type of paper, pollutant, livestock, and three main influence factors- indoor environment, rearing system, and manure management.

Most of the documents analyzed (more than $45 \%$ ) were related to poultry and pigs. Unsurprisingly, the most cited pollutant was ammonia (in more than $20 \%$ of publications). Although it is not the most dangerous pollutant in the animal industry, it is perhaps the biggest problem in terms of the concentration of pollutants produced in indoor livestock, mainly because of the large poultry production.

Approximately $1 / 5$ of the documents analyzed discussed the theme of air pollutants in indoor animal production in a general or generic way, without specifying the type of animal. Considering the relevance that poultry and pig farming have on indoor animal production, we could expect that a large fraction of such generic papers would also apply to pigs and poultry. 
Among the three factors analyzed in this article that influence the production and emission of pollutants in an animal building, the breeding system was the most cited and considered in the publications studied. However, the influence of the building's indoor microclimate was above the influence of manure management in number of publications.

\section{Pollutants In Livestock Buildings}

Human activities release greenhouse gas (GHG) into the atmosphere, although GHG can also occur naturally in the (IPCC 2006). In 1997, many countries approved the Kyoto Protocol intending on reducing anthropogenic GHG emissions, and in 1999 the Gothenburg Protocol agreed to reduce emissions of ammonia $\left(\mathrm{NH}_{3}\right)$, sulfur, nitric oxides, and volatile organic compounds $(\mathrm{VOC})$, reinforcing the previous agreement. Pursuant to this, European Union countries are required to reduce GHG emissions by adopting the Gothenburg and Kyoto protocols, in the Directive 2001/81/EC (European Commission Publication 2001), and the Directive 2010/75/EU, known as Industrial Emission Directive (IED) (European Commission Publication 2010).

Animal production is a significant source of emissions. Currently, gaseous emissions from livestock production are considered an important issue because of their impact on health and the environment; and they have been taken in by public agencies and government agendas. Livestock processes play an important role in climate change and may cause negative impacts on the ecosystems, including air pollution (Cortus et al. 2015).

Atmospheric water vapor $\left(\mathrm{H}_{2} \mathrm{O}\right)$, carbon dioxide $\left(\mathrm{CO}_{2}\right)$, methane $\left(\mathrm{CH}_{4}\right)$, and nitrous oxide $\left(\mathrm{N}_{2} \mathrm{O}\right)$, are wellknown GHG related to and the thermal equilibrium of the biosphere, and their emission trends have been tied to climate change. Water vapor has a very variable content on the atmosphere and follows the water and climate cycles, and $\mathrm{CO}_{2}$ is tightly related to both natural phenomena (i.e., respiration, decomposition, plant intake and ocean absorption and immobilization) and anthropic intervention (fuel burning, vegetation cover change). On the other hand, $\mathrm{CH}_{4}$ and $\mathrm{N}_{2} \mathrm{O}$ are of particular interest as their $\mathrm{CO}_{2}$ eq values are respectively $21 \mathrm{x}$ and $310 \mathrm{x}$ by mol (Solomon et al. 2007). Moreover, $\mathrm{N}_{2} \mathrm{O}$ emissions contribute to the depletion of ozone, via stratospheric conversion of $\mathrm{N}_{2} \mathrm{O}$ to nitric oxide (NO) (Olivier et al. 1998). $\mathrm{CH}_{4}$ and $\mathrm{N}_{2} \mathrm{O}$ emissions from various livestock sectors have been estimated in many countries following the Intergovernmental Panel on Climate Change (IPCC) guidelines (Cederberg et al. 2009; Vergé et al. 2009; Lesschen et al. 2011; EPA 2012; Liang et al. 2013).

The magnitude of GHG emissions from livestock production depends basically on the type of animal, rearing method/system, manure management, and indoor/outdoor climate conditions (Stinn et al. 2014; Richardson et al. 2020), (Fig. 4).

Several papers have identified the factors that affect emissions in animal buildings, mainly related to different climate environments and management methods (rearing), and usually focusing on odor and environmental impacts that reach the outside by ventilation (Stinn et al. 2014). Some authors proposed 
enteric fermentation and manure management as two key source categories for overall livestock-related GHG emissions (EPA 2009, 2010; Stinn et al. 2014; Sun et al. 2017).

Enteric fermentation and manure management are the main sources of $\mathrm{GHG}$ emissions from animal production. In 2018, $46 \%$ of $\mathrm{CO}_{2}$ emissions, $78 \%$ of $\mathrm{CH}_{4}$ emissions and $6 \%$ of $\mathrm{N}_{2} \mathrm{O}$ emissions in agriculture from enteric fermentation + manure management (FAO 2020). In Spain, livestock contributed over $35 \%$ of all $\mathrm{CH}_{4}$ emissions in 2017 , of which $75 \%$ came from cattle ( $62 \%$ from meat cattle alone) (Gobierno de España 2019).

Many papers reported emission rates. The main pollutants described in animal buildings are airborne microorganisms, $\mathrm{CH}_{4}, \mathrm{CO}_{2}, \mathrm{H}_{2} \mathrm{~S}, \mathrm{NH}_{3}, \mathrm{~N}_{2} \mathrm{O}, \mathrm{PM}$ and VOC (Ni 2015; Ni et al. 2021). Some authors classified animal pollutants into four groups: gases, odors, particulate matter, and volatile organic compounds(Ni et al. 2012b, 2017; Ni 2015).

$\mathrm{NH}_{3}$ is one of the most recognized harmful element that is produced from animal wastes(EPA 2008; Méda et al. 2015; Costantino et al. 2020); worldwide, $65 \%$ of anthropogenic emissions of $\mathrm{NH}_{3}$ originate in the livestock sector (Shen et al. 2019). Poultry production emissions are higher than any other animal production, mainly because of a dense animal occupation, and constitute the major environmental problem for poultry farming. In contrast, while poultry buildings are a significant source of $\mathrm{CO}_{2}, \mathrm{CH}_{4}, \mathrm{NH}_{3}$, and $\mathrm{N}_{2} \mathrm{O}$ emissions generating from the bedding, animal excreta, or uric acid decomposing into urea, followed by $\mathrm{NH}_{3}$ and $\mathrm{CO}_{2}$ volatilization promoted by urease enzyme, $\mathrm{CH}_{4}$ and $\mathrm{N}_{2} \mathrm{O}$ emissions from poultry facilities usually are lower than that of cattle or pig production; swine production buildings usually show high concentrations of $\mathrm{NH}_{3}, \mathrm{CO}_{2}$, and $\mathrm{PM}$, that have been found to affect negatively the health of both animals and humans (Ulens et al. 2014; Xu et al. 2017).

Thus, the type of contaminants (and, indeed, also their effects in both animals' and worker's health) will differ according to the type of both animal production and management in the animal buildings, although their global effect must also take into account how much each type of production and management represents in the sector. For example, pork meat is more consumed than poultry across the world (FAO 2011), and therefore their contribution to the global emission form $\mathrm{NH}_{3}$ becomes even more significant.

While a reduction of meat consumption would most certainly lead to a corresponding reduction in emissions, current expectations are that consumption will instead grow alongside world population and expansion of indoor animal production, with a projected increase in global meat consumption by $70 \%$ by 2050, mainly concentrating in developing countries with more intensive animal production (FAO 2011). To counter this trend it is necessary to develop strategies to reduce pollutants in the livestock production building, where air quality is worse due to higher emissions per square meter (Nicholson et al. 2004).

We will discuss below the main air pollutants found in livestock buildings, considering the effects on animal health and wellbeing, production efficiency, and the subsequent environmental impacts. 


\subsection{Airborne microorganisms: fungal spores and bacteria}

Airborne microorganisms (mainly bacteria, fungi, actinomycetes, viruses, and some archaea) are omnipresent, lifted from the soil, water/seawater, vegetation, and other places (Stetzenbach et al. 2004; Zhai et al. 2018)

One of the most common airborne microorganisms is fungal spores, which can be hundreds of times more frequent than other particles like pollen grains(Ebner et al. 1992; Takahashi 1997). On average, one person inhales an air content of nearly $10 \mathrm{~m}^{3} /$ day mostly containing fungal spores ranging from 0.65 to 3.3 $\mu \mathrm{m}$ in size (Dueker et al. 2012; Lee and Liao 2014; Zhai et al. 2018).

High rates of airborne microorganisms occur in animal building and their impact is not restricted to the buildings themselves, as they can spread through natural airflow, affecting the IAQ and increasing the regional health risk (Seedorf et al. 1998; Huijskens et al. 2016). Indoor animal housings influence the transmission of airborne microorganisms significantly and may contribute to contamination of industries of food processing (Geornaras et al. 1996; Whyte et al. 2001; Lues et al. 2007), according to the type of activity. For example, in laying-hen houses, where bacterial species are presented at high concentrations leading to food safety problems because bioparticles may be deposited to the eggshell, contaminating the table eggs (Seedorf et al. 1998; De Reu et al. 2005, 2008; Vuèemilo et al. 2010; Hannah et al. 2011; Ahmed et al. 2013).

Fusarium species are frequently found in animal feed. (Hanhela et al. 1995) detected airborne spores of Fusarium species during grain handling from 32 farms in Finland. While concentrations were low, they found Fusaria in $77 \%$ of grain and feed samples. A large variety of trichothecenes (a group of mycotoxins) from Fusaria have been identified from different types of cereals for animal feed in different geographical regions (WHO 1990).

Both fungal spores and bacteria usually attach to solid particulates, although they can also be found as individual bacterial particles (Zhao et al. 2015, 2016). In animal buildings, airborne microorganisms usually occur in feed zones, animal bedding, and manure (bedding + excreta), where manure is the most important. Fecal contamination, for instance, is a well-known bacterial problem that some authors noticed. In chicken-slaughtering facilities, the presence of Escherichia coli in chicken carcasses, Staphylococcus aureus in slaughtering environments, Pseudomonas aeruginosa in food processing environments are pathogens related to hygiene habits of employees. (Lues et al. 2007) alerted to a high rate of airborne microorganisms measured, highlighting the importance of maintaining a low microbial level before the processing stage.

A significant concern about these aerial contaminants is, in many cases, their relevant effect on the health of animals and farmers, as they can cause diseases such as allergic reactions or asthma. Hence, poor IAQ and building emissions of airborne microorganisms are key indicators of workspace health for farmers, animal welfare, farm efficiency and productivity, food safety, and environmental impact (Zhao et al. 2016; Costantino et al. 2020), and a reduction of bioparticle levels to ensure healthy and safe 
conditions at the animal production workplace is as desirable as, and likely leading to, safer exhaust air from animal buildings.

Table 2 condenses the main aspects of airborne microorganisms.

Table 2

Airborne microorganisms in livestock buildings.

\begin{tabular}{|c|c|}
\hline Origin & $\begin{array}{l}\text { - Moldy hay and foods. } \\
\text { - Unhygienic bedding animals with excreta. } \\
\text { - Animal feed operations. } \\
\text { - Manure. }\end{array}$ \\
\hline Characteristics & $\begin{array}{l}\cdot \text { Size }=0.65-3.3 \mu \mathrm{m} \\
\cdot \text { Individual particles or clusters or attached to particulate matters. }\end{array}$ \\
\hline Facilitators & $\begin{array}{l}\text { - Wet and humid conditions induce decomposition of raw organic materials. } \\
\text { - Unhygienic feeding trough and bedding. } \\
\text { - Stored straws and fodders. } \\
\text { - Animal movement and activities. }\end{array}$ \\
\hline Effects & $\begin{array}{l}\text { - Nasal and ocular diseases through mucosa contact. } \\
\text { - Hay fever and other allergies by particles }>10 \mu \mathrm{m} \text { contacting the nasopharynx. } \\
\text { - Asthma and other allergic reactions by particles }<10 \mu \mathrm{m} \text { reaching the lower } \\
\text { airways and lungs. } \\
\text {-Weak immunity, slow growth, and low feed conversion efficiency. }\end{array}$ \\
\hline
\end{tabular}

\subsection{Methane $\left(\mathrm{CH}_{4}\right)$}

In 2018, agriculture produced more than 142 million tons of methane through burning, cultivation activities, manure management (7\%) and most importantly, enteric fermentation by bacteria in the digestive tracts of animals (71\%) (FAO 2020). This scenario affords a deep concern because $\mathrm{CH}_{4}$ is a GHG emission, and the livestock production does not stop growing.

Enteric fermentation is a natural process inherent to the largely anaerobic nature of digestion (especially in ruminants), and emissions will depend on the population size and trophic habit of livestock. On the other hand, manure management prompts a temporal succession of microbial processes, where substrates are converted into volatile fatty acids, $\mathrm{CO}_{2}$, and hydrogen $\left(\mathrm{H}_{2}\right)$, increasing the temperature of the manure, and converting these products into methane (Hellmann et al. 1997; Moss et al. 2000; Olesen et al. 2006; Monteny et al. 2006; Philippe and Nicks 2015). 
$\mathrm{CH}_{4}$ production from manure may be estimated based on volatile solids in the excreted or organic matter (IPCC 2006). It is affected by low oxygen content, high temperature, high moisture in manure, a high level of degradable organic matter, a low redox potential, a neutral $\mathrm{pH}$, and a $\mathrm{C} / \mathrm{N}$ ratio between 15 and 30 (Amon et al. 2006; Kebreab et al. 2006).

Dairy farms and cattle production, in general, is taken as the most important source of $\mathrm{CH}_{4}$ emissions in indoor livestock, as the involved ruminants produce more methane per unit feed than other types such as pigs or poultry. Methane depends on each animal physiological stage, and so emissions have a large range of variation. It can be influenced by age and herd of the animals, and diet quality and feed intake (Philippe and Nicks 2015; Rotz 2018).

The type of housing in dairy farms (free stall barns with solid floors, barns with slatted floors and a collection pit below, bedded pack barns, an open lots) and the kind of stored manure may also affect the release of $\mathrm{CH}_{4}$ emissions (Webb et al. 2012; Rotz 2018; Kumari et al. 2020). Manure characteristics can significantly vary as they depend on the production factors, such as the type of building, rearing, feed, and facilities (straw supply, slurry separation, etc.) (Mathot et al. 2012).

Table 3 summarizes the main aspects of methane in farming.

Table 3

Main aspects of methane in animal buildings.

\begin{tabular}{|ll|}
\hline Origin & $\cdot$ Anaerobic degradation of organic matter. \\
\hline Characteristics & $\cdot$ Enteric fermentation. \\
& $\cdot \mathrm{CH}_{4}$ emissions vary with feed quality and intake and among animals of the same \\
& $\cdot \mathrm{CH}_{4}$ production favored by lack of oxygen, high temperature, a high level of \\
& degradable organic matter, high moisture content, a low redox potential, a neutral \\
$\mathrm{pH}$, and a C/N ratio of between 15 and 30. & \\
& $\cdot$ Swift removal of manure reduces $\mathrm{CH}_{4}$ emissions. \\
& $\cdot$ Increased animal activities, mainly feeding that leads to digestive action. \\
& $\cdot$ Higher temperatures on manure stored. \\
& $\cdot$ Nutritional factors: feed concentrate composition, maturity of harvested forages \\
and type of silage. & $\cdot$ Malodors. \\
Effects & $\cdot$ No direct negative effect on livestock. \\
& $\cdot$ Powerful greenhouse gas.
\end{tabular}


$\mathrm{CO}_{2}$ in animal production is a considerable problem when, in livestock confinement buildings, the production is overly dense, i.e., too many animals sharing, and breathing in, a confined space, however large. $\mathrm{CO}_{2}$ can also be originated from manure breakdown, although for both cases, breathing and manure, there are consequences on animal health and welfare when high concentrations of gas are reached (Ni et al. 2012a, 2017; Xie et al. 2017).

Although $\mathrm{CO}_{2}$ is renewable and non-toxic at normal atmospheric concentrations, the release of considerable amounts contributes to global warming (Alonso-Moreno et al. 2018). $\mathrm{CO}_{2}$ concentration is normally used to estimate ventilation rate in animal houses and, consequently, the contaminated airflow is exhaled from the indoor to outdoor, leading to environmental impact (Groot Koerkamp et al. 1998; Liang et al. 2005).

The animal production types most related to high population densities are poultry and swine. In broiler houses, thousands of animals are reared together, and high $\mathrm{CO}_{2}$ concentrations from breathing are reached, with negative effects due to both the direct effect of the gas and the decrease in the oxygen concentration (McGovern et al. 2001).

According to (Gerritzen et al. 2007), when the instantaneous $\mathrm{CO}_{2}$ concentration reaches $2,4 \%$, effects can be noticed in broilers. Still higher concentrations may lead to more severe health problems such as gasp and convulsions. However, lower concentrations held during longer exposure times could also affect the poultry health; for example, when broilers are exposed up to $6,000 \mathrm{ppm}$ of $\mathrm{CO}_{2}$ for two weeks their bodyweight is depressed and late mortality increases (Olanrewaju et al. 2008).

To minimize these problems, regulations were established, and concentration limits were assigned. For example, the European Council Directive 2007/43/EC (European Commission Publication 2007) prescribes a maximum density of $33 \mathrm{~kg}$ of broilers per $\mathrm{m}^{2}$ for non-monitored productions, and $42 \mathrm{~kg}$ of broilers per $\mathrm{m}^{2}$ when a program of both $\mathrm{CO}_{2}$ monitoring and environmental control to keep $\mathrm{CO}_{2}$ concentration below 3,000 ppm are enforced. These requirements are used for both animal welfare and quality-meat production in security-food (Costantino et al. 2020).

On the other hand, in swine production with a high-density of animals, in addition to exhalation by pigs $\mathrm{CO}_{2}$ comes from manure breakdown (Philippe and Nicks 2015). In manure, according to (Jeppsson 2000) and (Wolter et al. 2004), $\mathrm{CO}_{2}$ may have originated from three sources: 1 ) the rapid hydrolysis of urea into $\mathrm{NH}_{3}$ and $\mathrm{CO}_{2}$ catalyzed by the enzyme urease; 2 ) the anaerobic fermentation of organic matter into intermediate volatile fatty acids, $\mathrm{CH}_{4}$ and $\mathrm{CO}_{2}$; and, 3) the aerobic degradation of organic matter.

Table 4 summarizes the characteristics of $\mathrm{CO}_{2}$ in animal production. 
Table 4

Presence of carbon dioxide in indoor animal production.

\begin{tabular}{|c|c|}
\hline Origin & $\begin{array}{l}\text { - Animal respiration. } \\
\text { - Manure breakdown. } \\
\text { - Anaerobic fermentation of organic matter. } \\
\text { - Aerobic degradation of organic matter. }\end{array}$ \\
\hline Characteristics & $\begin{array}{l}\text { - Renewable. } \\
\text { - Easily handled and stored. } \\
\text { • Essentially non-toxic at normal levels. }\end{array}$ \\
\hline Facilitators & $\begin{array}{l}\text { - Seasonal and diurnal activity patterns. } \\
\text { - Higher temperatures. }\end{array}$ \\
\hline Effects & $\begin{array}{l}\text { - Decreasing of the oxygen concentration. } \\
\text { - Cause gasp and convulsions in broilers. } \\
\text { - Loss on weight and increase in mortality in broilers. }\end{array}$ \\
\hline
\end{tabular}

\subsection{Hydrogen sulfide $\left(\mathrm{H}_{2} \mathrm{~S}\right)$}

As a key component of the sulfur cycle, $\mathrm{H}_{2} \mathrm{~S}$ is a colorless, potentially harmful gas (although in very low concentration has low effect) produced in nature through the anaerobic breakdown of sulfate by bacteria. Nevertheless, hydrogen sulfide can be produced from human activities through various industrial practices and by the degradation of sulfur-containing protein in mammals (EPA 2003).

In livestock production, $\mathrm{H}_{2} \mathrm{~S}$ usually derives from manure breakdown (anaerobic decomposition) through two distinct ways: 1) mineralization of organic sulfur compounds; and 2) reduction of oxidized inorganic sulfur compounds (EPA 2003).

Generally, low $\mathrm{H}_{2} \mathrm{~S}$ concentrations are easily perceived, and long or extend gas exposure are taken as toxic and acutely dangerous to humans and animals: injury with chronic exposure at $10 \mathrm{ppm}$ and serious injury or death at $>500$ ppm ( $\mathrm{Ni}$ et al. 2012a, 2017; Lee et al. 2020). Even at a low gas concentration of less than $0.3 \mathrm{ppm}, \mathrm{H}_{2} \mathrm{~S}$ can be noticed by the human nose as an odorous gas with its unpleasant "rotten egg" smell (Blunden et al. 2008). However, at higher concentrations (>100 ppm) it may dangerously dampen the sense of smell (NRC 2009), negating the warning potential of odor.

Furthermore, $\mathrm{H}_{2} \mathrm{~S}$ is corrosive, explosive (at $4.3-45 \%$ by volume in air), and flammable $\left(260^{\circ} \mathrm{C}\right.$ ignition temperature) (Malone Rubright et al. 2017). These features have led authors to consider $\mathrm{H}_{2} \mathrm{~S}$ one of the most dangerous gases in animal buildings and manure storage (Xie et al. 2017). 
In livestock production, pig rearing is known as the animal production which has severe problems with $\mathrm{H}_{2} \mathrm{~S}$. And, in ruminants, the generation of large quantities of hydrogen sulfide depresses ruminal motility and cause severe distress to the nervous and respiratory systems (Kandylis 1984).

Details of $\mathrm{H}_{2} \mathrm{~S}$ in animal production are shown in Table 5.

Table 5

Characteristics of hydrogen sulfide in livestock buildings.

\begin{tabular}{|l|l|}
\hline Origin & $\cdot$ Anaerobic reduction of sulfate by bacteria (manure). \\
\hline Characteristics & $\cdot$. Cogradation of sulfur-containing protein in mammals. \\
& $\cdot$ Toxic: one of the most dangerous gases. \\
& $\cdot$ Rotten egg smell. \\
\hline Facilitators & $\cdot$ Long-term manure storage. \\
\hline Effects & $\cdot$ Lower airflow rate. \\
& $\cdot$ Injury and death in critically high concentration. \\
& $\cdot$ Lesions of respiratory and digestive system.
\end{tabular}

\subsection{Ammonia $\left(\mathrm{NH}_{3}\right)$}

The microbial decomposition of the organic part of the manure is the main source of ammonia in animal houses. $\mathrm{NH}_{3}$ is generated from animal excreta (urine and feces) present on the floors of the buildings, generally beddings and pits (Watt et al. 2010; Bjerg et al. 2013). Research has shown that ammonia release depends on when in the day urea is deposited, although the enzymatic degradation of urea may occur over time (EPA 2001; Bjerg et al. 2013).

When mixed into the atmosphere, the ammonia lifetime tends to be short (five days or less), and it is generally located near its generation site (Blunden et al. 2008). However, when $\mathrm{NH}_{3}$ is associated with other substances, mainly PM, it can form ammonium aerosols, such as ammonium sulfate, -nitrate, and chloride. In aerosol form, $\mathrm{NH}_{3}$ can be transported far from the source by airflow and can increase its lifetime up to 15 days (Blunden et al. 2008; Carew 2010).

Besides, $\mathrm{NH}_{3}$ is also considered a significant environmental impact agent because it may contribute to the acidification of soil and nitrogen deposition in ecosystems when emissions from the indoor livestock production reach the outdoor atmospheric environment (NRC 2003). Additionally, $\mathrm{NH}_{3}$ emissions can generate nitrous oxide $\left(\mathrm{N}_{2} \mathrm{O}\right)$, a $\mathrm{GHG}$, and secondary particles (Hallquist et al. 2009). 
$\mathrm{NH}_{3}$ emissions from agricultural activities amount to more than $94 \%$ of the total anthropogenic emissions (EEA 2017), and 75\% come from manure management in livestock production. From all livestock activities, cattle, swine, and poultry generate $53 \%, 25 \%$, and $15 \%$ of $\mathrm{NH}_{3}$ emissions, respectively (Webb et al. 2005; Oenema et al. 2007).

Ammonia is the main contaminant in poultry buildings. Its high capacity to latch on to other particles and substances because of its sharply hydrophilic base can make it pervasive, decreasing health, welfare, and performance of the animals, for instance impacting feed intake and weight gain (Seedorf and Hartung 1999; Kristensen et al. 2000; Popescu et al. 2010; Barrasa et al. 2012).

Indoor swine production also suffers from the consequences of poor IAQ by ammonia contamination, through respiratory diseases in piglets and farmworkers, and seriously impacts ecosystems as well (Mosquera et al. 2005; Xie et al. 2017). Because of the extent of ammonia-related issues in swine production, the European Integrated Pollution Prevention and Control convention mandates mitigation actions for $\mathrm{NH}_{3}$ emission following Best Available Techniques (BAT) principles in pig fattening buildings with more than 2000 animals (Ulens et al. 2014).

Details on the origin, characteristics, facilitators, and effects of ammonia in indoor animal production are presented in Table 6. 
Table 6

Ammonia in animal buildings.

\begin{tabular}{|c|c|}
\hline \multirow[t]{3}{*}{ Origin } & - Microbial decomposition of organic compounds. \\
\hline & - Manure and bedding material. \\
\hline & - Deposits of urine and feces. \\
\hline \multirow[t]{4}{*}{ Characteristics } & - Attaching to fine particulate matter. \\
\hline & - Urea is converted to ammonia by the enzyme urease. \\
\hline & - Noxious and odorous. \\
\hline & • Highly hydrophilic base. \\
\hline \multirow[t]{4}{*}{ Facilitators } & - Characteristics of the manure. \\
\hline & - Livestock management practices. \\
\hline & - Airflow characteristics above the manure surface. \\
\hline & - Higher temperatures (same airflow rate) and lower air movement. \\
\hline \multirow[t]{5}{*}{ Effects } & - Reduction of weight gains. \\
\hline & $\begin{array}{l}\text { - In broilers: ocular damage, mucosal inflammation, enhances susceptibility to } \\
\text { respiratory diseases and bacterial contamination of the lungs. }\end{array}$ \\
\hline & - Several infections. \\
\hline & - Rhinitis atrophic. \\
\hline & • Higher expression of gene inhibitor growth and breast muscle development. \\
\hline
\end{tabular}

\subsection{Nitrous oxide $\left(\mathrm{N}_{2} \mathrm{O}\right)$}

Although $\mathrm{N}_{2} \mathrm{O}$ origins are still in need of much research, it is suggested that, worldwide, more than $65 \%$ of $\mathrm{N}_{2} \mathrm{O}$ emissions come from agricultural activities and almost $50 \%$ are produced from animal manure: manure management, manure applied to soils, and manure left on pasture (FAO 2020). There is thus a significant drive to mitigate this GHG emission through improved manure management, avoiding, for example, emissions from leaching, runoff, and volatile nitrogen from wastes deposited in pasture or lagoons (Fabbri et al. 2007; Cornejo and Wilkie 2010).

$\mathrm{N}_{2} \mathrm{O}$ from livestock depends on the chemical and organic composition of the manure (oxygen, nitrogen, carbon, and liquid content), its storage and management, and on the bacteria responsible for decomposition process (Monteny et al. 2001; IPCC 2006; Amon et al. 2006; Cornejo and Wilkie 2010).

Before $\mathrm{N}_{2} \mathrm{O}$ can be emitted from manure, ammonification of urea (either direct in urine from ruminants or indirect, through the conversion of uric acid to urea, in excreta from birds) must happen first (Monteny et al. 2001). The ammonification process is well understood and described for urine and uric acid, excreted 
by cattle/pigs and poultry, respectively. The ammonium produced is then oxidized first to nitrite and then to nitrate by nitrifying bacteria under the conditions of a sufficient supply of oxygen (nitrification) (Monteny et al. 2001; Dong et al. 2007). Denitrification can then occur in nitrified slurry (in which ammonium has been oxidized to nitrate) and in soils (nitrate from chemical fertilizers) when denitrifying bacteria reduce nitrates back to gaseous forms that escape to the atmosphere (Monteny et al. 2001).

Besides becoming a $\mathrm{GHG}$ emission, the production of $\mathrm{N}_{2} \mathrm{O}$ from manure reduces the nitrogen content of animal waste. This fact decreases the value of animal manure as an organic fertilizer in crops, especially to organic food production farms (Dekker et al. 2011).

Historically, GHG emissions from stored animal manure and different managements of manure have been widely researched by many authors (Duxbury 1994; Jarvis and Pain 1994; Mosier 1994; Van Amstel and Swart 1994; Khan et al. 1997). However, in contrast to $\mathrm{NH}_{3}$, fewer data on the emissions of $\mathrm{N}_{2} \mathrm{O}$ from animal houses are available (Zhu et al. 2011; Fournel et al. 2011; Shepherd et al. 2015; Alberdi et al. 2016). The published data suggest, however, that $\mathrm{N}_{2} \mathrm{O}$ concentrations in livestock production are generally low. In a study in a fattening pig house, (Zong et al. 2015) reported quite low $\mathrm{N}_{2} \mathrm{O}$ concentrations $(0.32-0.5 \mathrm{ppm})$ independent of the airflow characteristic and periods of rearing, and concluded that $\mathrm{N}_{2} \mathrm{O}$ emissions were negligible. The authors explained that not both aerobic and anaerobic conditions could be observed to nitrification and denitrification processes, respectively, in the waste slurry.

In poultry houses, $\mathrm{N}_{2} \mathrm{O}$ emissions are very low and lower than other broiler pollutants, like $\mathrm{NH}_{3}$, and lower than in other livestock categories, e.g., dairy cattle and swine (Groot Koerkamp et al. 1998; Alberdi et al. 2016). Low $\mathrm{N}_{2} \mathrm{O}$ concentrations have also been observed in laying-hen houses (Jungbluth et al. 2001; Fabbri et al. 2007; Alberdi et al. 2016; Pereira et al. 2018). Moreover, (Alberdi et al. 2016) reported low nitrate content in hen manure, resulting in low denitrification.

On the other hand, even though it may represent a small percentage of all emissions as compared to other gasses, $\mathrm{N}_{2} \mathrm{O}$ is a strong $\mathrm{GHG}$, having a global warming potential almost three hundred times higher than that of $\mathrm{CO}_{2}$ and a long residence time (EPA 2010) and its emission from animal manure occurs in all animal buildings globally (Table 7). Therefore, finding ways to mitigate its production through manure management becomes an important task. 
Table 7

Key aspects of nitrous oxide in livestock buildings.

\begin{tabular}{|ll|}
\hline Origin & $\begin{array}{l}\text { - From ammonification of urea in manure, the ammonium produced is transformed } \\
\text { by nitrifying bacteria under the conditions of sufficient supply of oxygen } \\
\text { (nitrification). } \\
\text { - Nitrates in nitrified slurry experiment denitrification to gaseous } \mathrm{N}_{2} \mathrm{O} .\end{array}$ \\
\hline Characteristics & $\begin{array}{l}\text { - Significant greenhouse gas emission and consequently global warming and } \\
\text { climate change. }\end{array}$ \\
\hline Facilitators & $\begin{array}{l}\text { - } \mathrm{N}_{2} \mathrm{O} \text { is originated from manure decomposition process by bacteria. } \\
\text { - It depends directly on composition of manure, storage time and type of manure } \\
\text { management. }\end{array}$ \\
\hline Effects & $\cdot$ No direct negative effect on livestock, but strong driver for global warming. \\
\hline
\end{tabular}

\subsection{Particulate matter (PM)}

PM is composed of fine airborne solid and/or liquid particles containing oxygen, carbon, silicon, phosphorus, nitrogen, and other substances (EEA 2020). Normally PM is classified according to their size and the most common categories are $10,2.5$, or $1 \mu \mathrm{m}$ aerodynamic diameter which are usually known as $\mathrm{PM}_{10}, \mathrm{PM}_{2.5}$, and $\mathrm{PM}_{1}$ respectively (European Commission Publication 1999) Table 8.

The electrostatic attraction on PM causes particle agglomeration and may significantly alter both size category and attached content, such as hazardous matter like bacteria and/or viruses added on PM (Harry 1978). Therefore, PM might become a hazard. The health effects of PM have been exhaustively studied, and no completely safe level of PM has been found (WHO 2013).

PM reduce IAQ in livestock production, compromising the health and welfare of animals and farmers (Banhazi et al. 2008; Cambra-López et al. 2010), and by spreading to the neighboring areas it becomes a pollutant causing environmental impact (Mostafa and Buescher 2011; Ni 2015).

(Van Ransbeeck et al. 2012) and (Van Ransbeeck et al. 2013) stated that PM load data, i.e. levels, spatial distribution, and time- and frequency-related changes, are important to estimate the health impact on animals and farmers and to define PM mitigation actions such as indoor airflow assurance.

Many authors reported that poultry and swine production generate more PM in livestock buildings when compared to e.g. dairy barns (Wang-Li et al. 2013; Mostafa et al. 2016, 2017; Yao et al. 2018; Shen et al. 2019). Horse stalls is a particular case of livestock building that attracted research because PM considerably affects the health of horses when they are inhaled (Rundell 2012; Ivester et al. 2012, 2014; Giles and Koehle 2014; Millerick-May et al. 2015; Nazarenko et al. 2018). 
Table 8

Presence of particulate matter in animal production.

\begin{tabular}{|c|c|}
\hline \multirow[t]{3}{*}{ Origin } & - All movements of solid materials (feed, bedding...). \\
\hline & - Deposited dust, mineral particles, and smoke. \\
\hline & - Coming from outside through the opens. \\
\hline \multirow[t]{8}{*}{ Characteristics } & • Fine solid or liquid particles. \\
\hline & $\cdot \mathrm{PM}_{10}<10 \mu \mathrm{m}$ diameter. \\
\hline & $\cdot \mathrm{PM}_{2.5}<2.5 \mu \mathrm{m}$ diameter. \\
\hline & $\cdot \mathrm{PM}_{1}<1 \mu \mathrm{m}$ diameter. \\
\hline & $\begin{array}{l}\text { - Can contain bacteria, viruses, mold and moldy feed, pollen, ashes, } \\
\text { microorganisms, dander, ammonia, solid matters, and others. }\end{array}$ \\
\hline & •PM 2-3 $\mu \mathrm{m}$ from feed dust. \\
\hline & •PM 4-5.5 $\mu \mathrm{m}$ from manure. \\
\hline & - Chemically, can contain oxygen, carbon, silicon, phosphorus, and nitrogen. \\
\hline \multirow[t]{5}{*}{ Facilitators } & - Ventilation and air movement. \\
\hline & - Animal movement and activities, mainly feeding. \\
\hline & - Density of indoor animals. \\
\hline & - Age of the animals. \\
\hline & - Temperature and relative humidity. \\
\hline \multirow[t]{4}{*}{ Effects } & - Pathogenic microorganism transportation. \\
\hline & - Foul odor compound transportation. \\
\hline & $\begin{array}{l}\text { - Chronic cough, phlegm, chronic bronchitis, chest tightness, respiratory allergic } \\
\text { reactions. }\end{array}$ \\
\hline & - Poor performance in racing horses. \\
\hline
\end{tabular}

\subsection{Volatile Organic Compounds (VOC)}

A complex variety of volatile organic compounds (VOC) accompany other pollutant emissions such as gases, bioaerosols, particles and odors in animal husbandry (Hafner et al. 2013; Douglas et al. 2018). This commonly occurs in livestock farms where the pollutant profile varies according to the farm's sections: indoor environment, manure storage, accumulated wastewater and the air above the surfaces of these waters, compost, and lagoons (Trabue et al. 2011; Ni et al. 2012b; Guffanti et al. 2018; Wang et al. 2021). 
VOC are carbon-containing molecules that, under normal conditions of temperature and pressure, vaporize and enter the local atmosphere according to their specific vapor pressure points. They are seen as a large group of organic chemical products, formed by molecules of different functional groups that present different physical-chemical behaviors, but having in common a certain volatility (Komilis et al. 2004). The most common examples are volatile fatty acids, alcohols, aldehydes, amines, aromatic hydrocarbons, carbonates, esters, ethers, ketones, sulfides, disulfides, mercaptans and heterocyclic nitrogen compounds (Filipy et al. 2006; Fang et al. 2012; Conti et al. 2020).

VOC can attach to the surface of solid particles, i.e., PM, and be thus transported to, and spread through, the atmosphere (Schneider et al. 2001; Martin et al. 2008; Cambra-López et al. 2010). However, VOCs can also be found at various places on a livestock farm that are completely decoupled from PM. For example, in silage products more than 50 different types of VOCs have been detected through emission monitoring (Chung et al. 2010; Howard et al. 2010; Hu et al. 2012). VOC contribute to tropospheric ozone production, which causes adverse health effects (Monks et al. 2009).

One of the biggest problems associated with the presence of VOC in a rural industry is their generally unpleasant odor, which causes discomfort of workers and neighbors (Table 9). Odor is defined by ISO 5492:2008 (ISO 2008) as an organoleptic attribute perceived by the olfactory organ (including nerves) when it smells certain volatile, pleasant or unpleasant substances. The odor can be considered to occur due to the interaction of different volatile chemical species, such as sulfur compounds (for example, sulfides, mercaptans), nitrogen compounds (for example, ammonia, amines) and volatile organic compounds (for example, esters, acids, aldehydes, ketones, alcohols) (Barth et al., 1984).

Table 9

Features of VOC in livestock buildings.

\begin{tabular}{|l|l|}
\hline Origin & $\begin{array}{l}\text { - Vaporization of molecules containing carbon. } \\
\cdot \text { Manure storage is a major source of odor causing VOCs. }\end{array}$ \\
\hline Characteristics & $\cdot$ VOC-odor is composed from miscellaneous chemicals. \\
\hline Facilitators & $\cdot$ Contribute to tropospheric ozone production. \\
\hline Effects & $\cdot$ Presence of PM in the air. \\
& $\cdot$ Malodorous and ozone production. \\
\hline
\end{tabular}

Malodorous conditions are usually associated with harmful air pollutants and unhealthy air conditions (Aatamila et al. 2011; Capelli et al. 2013). Unpleasant odors can cause negative emotional reactions in people, resulting in an important decreasing of the quality of life in the areas surrounding the livestock farms (Ni et al. 2012b; Palmiotto et al. 2014; Blanes-Vidal 2015), and discomfort due to the generation of odors in animal production is one of the main sources of complaints from people who are close to 
animal farms (Keck et al. 2018). As a result, over the years there has been a greater emphasis on controlling the impact of air pollutants exhaled from the livestock buildings and spread out in neighboring areas (Bibbiani and Russo 2012; Hayes et al. 2014; Ni 2015).

For evaluating odor concentration, olfactometry sensory measurements have been used as a standard method, and has been used to quantify odor concentrations from the animal slurry applied on the field (Hansen et al. 2006). The level of odor depends basically on the organic and inorganic odorous compounds (Zhu et al., 2016), and therefore these could be measured as proxies for odor sensitivity. However, a recent study investigated the odor emissions from cow and pig slurries used on the soil used dynamic olfactometry, without specifically quantifying VOC (Orzi et al. 2018).

Research have indicated that VOC can be considered biomarkers of decomposition associated to mortality, suggesting their use in animal production practices (Akdeniz et al. 2011; Costa and Akdeniz 2019). Several studies have explored the possibility of diagnosing pathologies in animals by identifying the VOCs produced by pathogens, pathogen-host interactions and biochemical pathways (Ellis et al. 2014). For example, VOC analysis has been explored as a method to diagnose bovine respiratory diseases, brucellosis, and bovine tuberculosis (Fend et al. 2005; Kumanan et al. 2009). In fact, VOC emitted from different areas of the living body can be considered as individual 'fingerprints', and pathological processes (such as infection and endogenous metabolic disorders) can influence those 'fingerprints' either by producing new VOC or changing their normal proportions. One of the main advantages of these techniques is that they are non-invasive diagnostic tools that do not require any manipulation of the animals. For these reasons, exploring volatile organic compounds is an area of research of increasing interest in veterinary medicine (Shirasu and Touhara 2011; Peled et al. 2012).

\section{Factors Affecting The Production Of Polluting Emissions}

Many variables can influence the generation and emission of gases, particulate matter, and microbial agents in livestock buildings. Temperature and relative air humidity, type of floor, presence of certain materials, movement and handling of indoor manure, the season of the year and period of the day are just a few examples (Méda et al. 2015).

Important decisions, such as the rearing system used in animal buildings, volume of production and stock, age of the herd, feed programs, indoor climate program, or manure management, are often dependent on the size and complexity of any given farm. In turn, all these choices affect IAQ and the production and spreading of pollutants (Shepherd et al. 2015; Zhao et al. 2015). Different animal housing systems may thus result in different pollutant emissions for the same livestock as much as the different livestock do.

(Philippe and Nicks 2015) argued that promoting positive responses in zootechnical performance of animals through welfare practices, like better building design based on animal wellbeing, implementation of bioclimatic strategies to control the indoor climate, or improvement in sanitary status, may lead to a 
decrease in emission levels. Improvements in animal welfare may indeed carry investment and operating costs, but high taxation on emissions generated can drive decisions in favor of mitigation techniques.

Now we will introduce a literature review for each group of variables and their relationship with the generated pollutants.

\subsection{Influence of indoor environment}

An indoor environment refers to a closed place, usually a shed, where animals in production are confined and are subject to a certain environment, determined by natural, artificial means, or both. However, the microclimate of these indoor environments, mainly temperature $(T)$, relative humidity $(R H)$, and ventilation, is frequently challenged by local climate parameters varying with the seasons and the airflow patterns.

Indoor T and $\mathrm{RH}$ changes depend primarily on the geographical location of the building. The greater the seasonal climatic amplitude, the greater variation of the indoor microclimate's $\mathrm{T}$ and $\mathrm{RH}$. And the higher the $\mathrm{T}$ and $\mathrm{RH}$, the lower the indoor animal activity and movement of animals, resulting in deterioration of animal welfare and, consequently, reduced productivity, matched by a corresponding reduction of pollutant emissions, as verified by (Ngwabie et al. 2011) in dairy cow buildings where increased air temperature resulted in reduced production and less release of $\mathrm{CH}_{4}$ by cows.

On the other hand, warm seasons leading to high indoor temperatures result in an increase of the chemical production of air pollutants due to the temperature effect on the chemical activity (catalyzing effect of chemical reactions) (Alberdi et al. 2016; Huang and Guo 2019). However, high temperatures demand more efficient airflow through the shed to remove heated air and allow fresher air in. Thus, the emissions will likely distribute more evenly throughout the building but will also be exhaled from livestock buildings in larger quantities, leading to important environmental impacts in surrounding areas.

Rural sheds are usually equipped with air cooling systems to avoid losses in productivity from poor animal welfare when temperature rises. These systems are installed when natural ventilation alone is not able to reduce thermal impacts on production. On the other hand, when the T of the region is low and the buildings require maintenance of the internal heat, i.e., a warmed environment, the flow of fresh and cold air along the indoor building tends to be drastically reduced.

Thus, pollutant emission dynamics are strongly altered by the indoor microclimate both in production / concentration and in the spreading through the indoor area. (Blunden et al. 2008) confirmed the seasonality in aerial pollutant emissions in pig houses, particularly to $\mathrm{NH}_{3}$ and $\mathrm{H}_{2} \mathrm{~S}$ concentrations, emphasizing the influence of the airflow through the building, which tends to be lower during the cold seasons than in the warm seasons. Seasonal variations in the GHG emissions by animals can thus happen (Dong et al., 2007), and regular measurements to ensure representative emissions data throughout the year become important. 
In general, all pollutant emissions in all types of animal production differ throughout the year. In layinghen houses, differences in $\mathrm{NH}_{3}$ and $\mathrm{CO}_{2}$ concentrations in different seasons were verified by (Alberdi et al. 2016; Ni et al. 2017), with higher concentrations in summer than in winter. However, there is a tendency for indoor $\mathrm{N}_{2} \mathrm{O}$ levels to increase in cold seasons in laying-hen cage houses because of less ventilation (Alberdi et al. 2016). In contrast, (Huang and Guo 2019) reported that $\mathrm{N}_{2} \mathrm{O}$ atmospheric emissions were higher in the mild and warm seasons because the ventilation led to an improved release of this aerial pollutant.

In regions where the seasons have no significant variation in the outdoor temperature, indoor emissions tend to change minimally during the year, because the indoor climate remains constant throughout the year if the airflow pattern can be maintained.

PM and indoor microclimate change have been extensively studied and correlated. Particulate matter have a strong dependence on RH and airflow (Gustafsson 1999; Puma and Maghirang 2000; Kim et al. 2005; Nannen and Bonn 2006; Bunney et al. 2017). (Shen et al. 2019) observed a positive correlation between $\mathrm{PM}$ and $\mathrm{RH}$, though not between $\mathrm{PM}$ and $\mathrm{T}$.

PM emissions can be taken as the major problem in horse stables during the cold seasons. But when an optimized ventilation system is applied, the respiratory diseases roughly decrease, indicating the importance of maintaining IAQ strategies independent of seasons and periods of the day in horse stalls (Elfman et al. 2011).

Temperature and relative air humidity are two important factors for developing microorganisms, especially fungi, promoting the acceleration of the decomposition of organic matter, such as feed and manure. (Xie et al. 2017) explained that a high RH could promote a catalytic effect, i.e., acceleration in microorganism reproduction, such as bacteria, fungi, and some parasites, resulting in a fast proliferation of these biological organisms and, thus, animal diseases.

Another effect of the high $\mathrm{RH}$ is increasing the speed of decomposition of organic compounds (excreta, feed, and manure), providing ideal conditions for microorganism growth and raising the airborne pollutant concentration (Adhikari et al. 2004; Xie et al. 2017). In indoor environments, higher T and RH are associated with the higher generation, release, and dispersal of fungal spore as observed by (Herrero and Zaldivar 1997) in cattle sheds.

(Blunden et al. 2008) confirmed the seasonality in aerial pollutant emissions in pig houses, particularly $\mathrm{NH}_{3}$ and $\mathrm{H}_{2} \mathrm{~S}$, emphasizing the influence of the airflow through the building, which tends to be lower during the cold seasons than during the warm seasons. Ensuring outdoor air exchange in livestock confined production is always essential to reduce temperature and relative air humidity, and to renew internal air evacuating contaminated air. This airflow maintains IAQ and therefore, promotes animal welfare and productivity. 
Adequate openings to natural ventilation are thus desirable in animal buildings, but when these are not possible or enough, mechanical ventilation should be considered to allow sufficient airflow through the shed according to IAQ requirements in animal production.

In cold climates, animals may not require as much fresh air to reduce temperature and achieve welfare, but nonetheless a renewal airflow is necessary to remove pollutants. On the other hand, in warm climates and hot and humid climates, a specific ventilation program must be designed to avoid poor IAQ associated to high $\mathrm{T}$ and $\mathrm{RH}$. This higher ventilation rate can also assist in diluting pollutant concentration along the sheds, such as e.g. bioparticles as observed by (Zhao et al. 2014) and (Zhao et al. 2016) in laying-hen houses.

The sheds can be naturally ventilated through large side openings and roof and ridge openings, although sheds with large openings in cold climates may have difficulty maintaining appropriate thermal conditions with too much cold air entering the building (Rong et al. 2014). This bioclimatic strategy drives fresh air by wind pressure or convection, allowing warmer air to escape through the roof openings while suctioning cold air through the lower openings. Both wind effect and convective (buoyancy) force lead to an economic reduction of electrical energy using mechanical ventilation (Koinakis 2005; Schulze and Eicker 2013).

However, (Rong et al. 2014) alerted that in buildings with large openings, it is almost impossible to clean the exhaust air, resulting in environmental pollution by exhalation to the atmosphere of $\mathrm{NH}_{3}, \mathrm{CH}_{4}$ and other airborne pollutants.

Mechanical systems demand substantial investments and running costs in the purchase and maintenance of equipment and consume electrical energy, increasing the cost of production besides producing an important noise level when they are switched on (Ecim-Djuric and Topisirovic 2010). However, mechanically-controlled ventilation also facilitates removal of indoor pollutants before exhaust, as air can be driven through point cleaning systems before release.

Estimating pollutant emission rates in naturally-ventilated buildings can be much more difficult than in mechanically-ventilated buildings (Ngwabie et al. 2009), given the complex connections between the outdoor wind and the indoor environment (Bjerg et al. 2013).

In open buildings, air exchange rates depend on both indoor parameters, such as temperature gradient and airflow, and outdoor parameters, like wind speed and surrounding topography (Ngwabie et al. 2009). These authors observed wide spatial and temporal variations in the concentration of $\mathrm{CO}_{2}, \mathrm{NH}_{3}$ and $\mathrm{CH}_{4}$, inside a naturally-ventilated barn. (Bjerg et al. 2013) modelled the concentration and spreading of $\mathrm{NH}_{3}$ above manure in livestock houses as a function of ventilation rate, air inlet conditions and temperature.

A significant influence of temperature and airflow (especially airflow momentum and intensity turbulence) on the rates of $\mathrm{NH}_{3}$ release from manure has been observed (Arogo et al. 1999; Ye et al. 2008; Rong et al. 2009; Saha et al. 2011). However, inside the building, airflow turbulence and natural wind 
variation reduce the accuracy of velocity data, and induce uncertainty about the airflow gradients and turbulence above surfaces that can potentially release pollutants, such as manure, bedding, and slurry (Bjerg et al. 2013).

As explained earlier, in a cold climate or weather environment livestock buildings reduce air exchange in order to maintain thermal comfort but must ensure enough internal airflow (called minimum ventilation rate) to control IAQ.

When minimum ventilation is used as hygiene air in animal houses, the focus should be placed on the worst pollutant emission, as it should afford the best relative IAQ improvement, rather than on some ready measurement. For example, in horse stables the minimum ventilation is usually established only to keep $\mathrm{RH}$ or $\mathrm{CO}_{2}$ levels within a threshold. However, this can result in dangerous levels of $\mathrm{NH}_{3}$ and PM, reducing the air quality and leading to poor health and welfare of the horses, as their respiratory tract particularly sensitive to high PM concentration (Katayama et al. 1995; Curtis et al. 1996; Holcombe et al. 2010; Kwiatkowska-Stenzel et al. 2014; Bøe et al. 2017). Low ventilation rate in combination with type of bedding material and hygiene practices also influence the $\mathrm{NH}_{3}$ and $\mathrm{PM}$ concentrations in horse stables (Clements and Pirie 2007; Fleming et al. 2009).

(Shen et al. 2019) linked pollutant concentrations with airflow speed to establish a possible correlation between them. The authors observed that there was an indirect correlation between $\mathrm{PM}$ and $\mathrm{NH}_{3}$ with airflow speed.

(Wålinder et al. 2011) measured pollutant emissions in a riding school stable before and after installing a ventilation system and reported the positive influence of an adequate ventilation program to maintain the levels of $\mathrm{CO}_{2}, \mathrm{NH}_{3}$, airborne microorganisms and $\mathrm{PM}$ below the respective hazardous concentrations for horses.

Ventilation systems can effectively remove odor nuisance in livestock buildings, but an inadequate airflow, on the other hand, can influence the odor propagation through the indoor areas due to the low intensity of air renewal. (Cheng et al. 2002) explained that pollutant emissions should effectively guide airflow patterns to animal buildings, i.e., the higher the concentration of pollutants in the air, the greater the airflow for a specific volume. However, (Young et al. 2000) described that when minimum ventilation is used to maintain air quality in cold climates, refreshing indoor air, the building's ventilation design must be carefully studied to obtain an effective cleaning of the indoor air, avoiding the maintenance of air pollutants in the closed environment.

Some modifications in animal buildings have been tested to increase the efficiency of the ventilation system to mitigate pollutant emissions. Partial Pit Ventilation (PPV) is a concept largely used in swine houses, and the results have been published as a successful solution for reducing emissions and increasing efficiency of the ventilation system in reducing the concentration of emissions (Saha et al. 2010; Wu et al. 2012b; Rong et al. 2014; Zong et al. 2015). (Rong et al. 2014) showed that PPV can benefit energy savings by making up for $10-30 \%$ of the maximum ventilation rate and, therefore, 
allowing for a corresponding reduction of electricity dedicated to mechanical ventilation. (Saha et al. 2010) studied $\mathrm{NH}_{3}$ emissions when a PPV system was used in a fattening pig house and observed a reduction of $42.6 \%$ in ammonia concentration as respects to a conventional ventilation system. Similar results were found by (Hansen et al. 2012).

In dairy cattle buildings, (Wu et al. 2012a) and (Wu et al. 2012b) also found increased efficiency in the reduction of emissions through experiments and numerical simulations, with a pollutant removal rate by pits in excess of $80 \%$, depending on the airflow condition above the floor. On the other hand, (Rong et al. 2014), found that the use of PPV leads to cumulate $64-83 \%$ of ammonia emissions in cattle buildings.

\subsection{Influence of rearing systems}

Pollutants in animal sheds are a function of the type of animal production - broilers, swine, cattle, eggs, etc. -, the rearing period or phase, for example, maternity or termination stage, and other variables. They affect the health and wellbeing of the animals, productivity, and sustainability (EPA 2004; Mostafa and Buescher 2011; Ni et al. 2012a; Zhao et al. 2015).

The rearing system can influence the generation of aerial pollutants because it affects several parameters, such as animal activities, airflow, feed management, and, principally, manure management. Materials used in bedding also strongly influence emissions.

Hygiene in the shed, especially in relation to manure, and controlled storage of the feed are determining factors to avoid contamination of the environment, mainly by microorganisms and also fungi, that can grow on aged animal food, moldy hay, manure (bedding + excreta) and that are usually associated with individual bacterial particles or attach to PM (Cambra-López et al. 2010, 2011; Smets et al. 2016; Zhao et al. 2016).

An unhygienic workplace could thus result in a high quantity of fungal spores being released in the air, causing infections or triggering respiratory disease both in farmers and animals (Adhikari et al. 2004; Rylander and Carvalheiro 2006; Cambra-López et al. 2010). Some authors have suggested that this problem can be alleviated by minimizing airborne microorganism levels in livestock buildings through severe mitigation actions to achieve healthy working conditions and quality in the animal growing environment (Seedorf et al. 1998; Zucker et al. 2000; Wales et al. 2006).

The bedding can also be considered a favorable place for the proliferation of microorganisms and production of PM. The movement of animals on it, which depends significantly on the type of rearing used, is a particular factor. For instance, in the cage-free hen house method, the high PM and airborne bacteria concentrations derived from the movements of the animals on the bedding (Zhao et al. 2015, 2016) and differed substantially from conventional cage houses (Zhao et al. 2016).

Disinfecting the litter could potentially reduce the contamination by litter bacteria such as $\mathrm{Gram}^{-}$bacteria and protect crops and pasture zones from fecal bacteria when the bedding is removed and used as a fertilizer support (Quarles et al. 1970; Soupir et al. 2006; Hannah et al. 2011). 
(Adhikari et al. 2004) studied cattle shed sections and observed a higher concentration of Nigrospora in the feed storage, especially the stacks of straw, which might serve as a local source of fungal spores. They found the toxic fungus $A$. flavus in stored straws and fodders for cows and called for an efficient IAQ program to prevent health hazards. Similar calls have been made by other authors, although some recognize that there is still insufficient comparative data about $\mathrm{NH}_{3}, \mathrm{GHG}$, and $\mathrm{PM}$ emissions from shed sections (Xin et al. 2011). Understanding the mechanisms of aerial pollutant emissions throughout sections will require stronger statistical correlations of different variables, connecting cause and effect (Xin et al. 2011; Ni et al. 2017).

In livestock indoor production, diurnal patterns associated to the rearing systems have been found in the dynamics of pollutant emissions. Likewise, the seasons can also introduce patterns especially when seasonality is strong, e.g., distinctly hot and cold seasons throughout the year. Both types of patterns combine to regulate the activity behavior of animals (feed intake, movement on the bed, natural behaviors in general), which in turn influence contaminant mobilization patterns. For example, lower activity in pig houses reduces PM concentrations and emission rates at night because of the changes according to both temporal and spatial behavior of the animals (Wang et al. 2002; Van Ransbeeck et al. 2012). (Mostafa and Buescher 2011) observed that in poultry houses, $P M$ emissions were higher during daytime and summer, and that they were higher in open aviaries than in cage systems. Similarly, (Zhao et al. 2016) observed that increased hen activity on the floor litter during the afternoon generated higher pollutant emission and bacterial particle levels than in the morning.

However, the period of the day did not seem to influence $\mathrm{NH}_{3}$ concentration in an enriched cage laying hen facility, while differences in $\mathrm{CO}_{2}$ emissions were low in a study by (Alberdi et al. 2016).

Feeding intervals within a given type of management or even a feeder area when animals are free to access feed significantly interfere with the production of particulates and move part of the feed to the floor or bedding in these areas, even becoming the main factor for higher PM emission rates in swine (O'Shaughnessy et al. 2002; Saha et al. 2011; Van Ransbeeck et al. 2012; Bunney et al. 2017; Shen et al. 2019).

In dairy production, feeding times of the cows also condition the development of the pollutant concentration rate because of increased animal activity. A correlation between gas emissions and feed programs in dairy buildings exists (Ngwabie et al. 2011).

Different production systems may lead to variable emission rates. In a study where different laying-hen houses were considered, (Zhao et al. 2016) observed that in aviary house systems, total bacteria concentrations and emission rates were much higher than both conventional cage house and enriched colony house systems.

In equine buildings, the inhalation exposure to PM was higher in stabled horses versus no-stabled horses, principally when the activities of the horses were walking and eating (Vandenput et al. 1997; Fleming et al. 2008; Nazarenko et al. 2018). 
Trying to mitigate high concentrations of PM in horse stables, (Nazarenko et al. 2018) investigated an alternative polymeric material, woody PET, for stall bedding. However, the use of woody PET resulted in increased PM concentration over natural straw, which is still considered the best bedding material for stables even when horse activity is high.

Several nutritional factors affect the rate of enteric $\mathrm{CH}_{4}$ production in ruminants, such as feed concentrate composition, the maturity of harvested forages, and the inclusion of maize silage at the expense of grass silage. However, although detailed information was available about nutritional conditions on dairy cattle farms (Arriaga et al. 2009), (Merino et al. 2011) alerted that a large number of differences among farms other than nutrition makes it difficult to ascertain the effect of feeding systems on $\mathrm{CH}_{4}$ release.

\subsection{Influence of manure management}

Total anthropogenic $\mathrm{CH}_{4}$ emission from enteric fermentation and manure management in farming activities is almost $80 \%$, and the methane released in the biosphere from agriculture is about $40 \%$ (FAO 2020). Manure management is the most discussed factor regarding emissions and the most important source of $\mathrm{NH}_{3}$ and $\mathrm{N}_{2} \mathrm{O}$ (Jungbluth et al. 2001).

When manure remains stored inside the building until the end of the production cycle emissions are higher than when manure is frequently removed from the building, which dramatically reduces emissions (Groot Koerkamp 1994; Weiske et al. 2006; Starmans and Van der Hoek 2007; Nimmermark et al. 2009; Dekker et al. 2011). Emissions from manure when it is taken out to external areas may also decrease because these outside areas have typically lower temperatures than indoor areas (Gustafsson et al. 2005; Nimmermark and Gustafsson 2005). Temperature, wind speed and airflow directions, $\mathrm{pH}$ and volume of the manure, among other factors, influence the emission dynamics of manure stored in livestock buildings (Sebacher et al. 1983; Khan et al. 1997; Park et al. 2019).

$\mathrm{N}_{2} \mathrm{O}$ is not likely to be produced from manure stored indoors in pits beneath the slatted floors, though this is the most common excreta storage system in pig and cattle farming (Monteny et al. 2001). $\mathrm{N}_{2} \mathrm{O}$ emissions are expected in housing systems that are based on solid manure. In these systems, animal excreta are either already in the form of solid manure (poultry) or are being collected in, e.g., straw or wood shavings (pig and cattle). However, manure deposited on the floor and/or pit promotes the release of $\mathrm{NH}_{3}$, though ammonia production and concentration will depend on the characteristics of the manure, the rearing, the microclimate in the building, and the airflow above the stored manure surface (Bjerg et al. 2013).

In recent decades, bedded systems have been used in swine buildings, achieving better welfare, odor nuisance, and GHG emissions (Philippe and Nicks 2015) than in the most common system based on a slatted floor where the animal excreta fell on a pit used to store slurry, although other authors could not observe a significant reduction in the indoor aerial pollutant concentrations when partly-slatted floors were used in lieu of fully slatted floors (Ulens et al. 2014). 
Whereas several factors influence emissions of $\mathrm{N}_{2} \mathrm{O}$ and complex interactions must occur among different sources, several authors found that certain materials, for example, mixed with animal waste, may lead to $\mathrm{N}_{2} \mathrm{O}$ reduction and thus can be considered efficient actions of emission mitigation (Duxbury 1994; Jarvis and Pain 1994; Kaiser et al. 1996; Amon et al. 2006). For instance, the addition of porous materials in an animal slurry to absorb the liquid phase can slow down the chemical reactions and, consequently, achieve aerial pollutant production. (Blanes-Vidal et al. 2008) verified that $\mathrm{N}_{2} \mathrm{O}$ almost reached zero-emission when maize silage and wood chips were added to pig slurry. However, other mixing materials such as straw may not be as efficient, as they can modify the physical characteristics of the animal waste, enhancing the alternate aerobic and anaerobic conditions that may promote $\mathrm{N}_{2} \mathrm{O}$ emissions (Blanes-Vidal et al. 2008; Hansen et al. 2020). Nonetheless, the use of straw in dairy cows bedding decreased total GHG emissions when the manure was stored indoor, even though there were significantly pollutant emission differences among the seasons of the year (warm, mild, and cold seasons) because of the temperature-dependent variation of the microorganism activity (Mathot et al. 2012). When compared to wooden chips, chopped straw used to cover manure slurry from dairy cattle decreased aeration, resulting in an increase of GHG emissions (Amon et al. 2006)

In free-stall barns, manure is normally removed every few hours to once a day by scraping or flushing. With this rapid removal of the manure, $\mathrm{CH}_{4}$ does not have time to build and indoor emissions are low. In contrast, with a slatted floor manure accumulates in a pit under the floor from a few weeks up to several months, and in a bedded pack barn, manure accumulates on the floor for a few months as more bedding material is being added over the winter to absorb moisture (Rotz 2018). Under the aerobic and anaerobic conditions found within the pit or manure pack, $\mathrm{N}_{2} \mathrm{O}$ and $\mathrm{CH}_{4}$ emissions become much greater, respectively. Manure also accumulates on an open lot, but the manure is spread in a thinner layer where the more aerobic conditions induce less GHG emission (Rotz 2018). On the other hand, the effect of high compaction of the bedding may also become less favorable for the generation of contaminants, especially those aerobic processes that require oxygen.

Displacement of manure is often related to the release of GHG. If there is not enough ventilation in the shed, manure movements within the shed will thus elevate indoor contaminant levels. Manure buildup promotes emissions and requires additional manure handling, compounding the problem. In any case, GHG will eventually find their way to the atmosphere through building exhalation. On the other hand, frequent removal of manure from the building may reduce indoor emissions and enhance IAQ.

\section{Conclusions}

There is a significant, demand-driven increase in the production of animal by-products worldwide. This is only possible through a considerable improvement and intensification of livestock production in controlled and closed buildings. However, emissions of pollutants such as airborne microorganisms, $\mathrm{CH}_{4}$, $\mathrm{CO}_{2}, \mathrm{H}_{2} \mathrm{~S}, \mathrm{NH}_{3}, \mathrm{~N}_{2} \mathrm{O}$, VOC and PM are intrinsic to the processes, and therefore IAQ is strongly affected and 
requires continuous and specialized attention including mechanical ventilation and constant monitoring for pollutant abatement (Ni and Heber 2010; Takai et al. 2013; Tullo et al. 2019).

Low IAQ affect both livestock and workers, and can also cause serious environmental impact problems on the neighborhood when the gases are exhaled from animal buildings. Achieving desirable IAQ following the environment guidelines of each country requires identification of the generated pollutants according to the type of animal production and its functional characteristics such as breed and welfare needs, as well as local climate, management actions or rearing, typology of building/shed and environmental control actuators, and analysis of the data collected through continuous monitoring. Mitigation procedures must consider all those factors and data for successful implementation.

According to our literature review, the most cited production variables that lead to changes in the characteristics of IAQ are the rearing system, indoor microclimate, and manure management. Although these three variables tend to be quite interrelated in a systemic view, a specific view of each variable is essential when selecting mitigating actions.

The production of pollutant gases derives from complex chemical reactions that strongly depend on the availability and quantity of specific compounds and on the conditions in the manure and its environment such as temperature, moisture content, presence of oxygen, surrounding air flow, physical characteristics of the deposits (porosity, compaction, specific surface, adsorption potential, etc.). Hence, the quantity of emissions is not just a direct function of the volume of manure generated by the livestock, but also of where and how it is generated, including microclimate conditions ( $T$ and $\mathrm{RH}$ ) of the manure storage sites, mixture with other components such as bedding or water, the dynamics of air flow through the building, and the effects of gas dispersion.

Solid particulate matter and microorganisms, attached or not to PM, also depend on all three factors (rearing, microclimate, manure). Fresh air intake for renewal and cleaning is also a source of PM in the indoor building. Microorganisms, on the other hand, depend on the organic matter and environmental conditions to reproduce and are linked to both the hygiene condition of the sheds and the health condition of the herds.

Herd management, bedding composition, and building typology and design (spaces for movement of the livestock, feeders and drinkers, manure storage areas for short and long periods, etc.) are also factors that influence qualitatively and quantitatively the production of air pollutants.

Manure management, especially bedding turning, removal, storage, and manure-bedding mixing operations, causes important concern about emissions in indoor livestock production. Most mitigating solutions aim at the physical-chemical treatment of manure, especially when they are deposited outside the shed. However, certain herding practices and manure-bedding mixtures can result in lower environmental impact even inside the building. 
The microclimate conditions of the shed are decisive for the development and propagation of indoor air emissions. Temperature and air flow are the predominant, interdependent microclimate variables, as ventilation conditions are primarily determined by the livestock's sensitivity to adverse thermal conditions, both high and low. These variables exert a significant influence on the production of pollutant emissions from manure, depending on the rearing system in place. A ventilation program in an animal building that does not consider emissions and their buildup could lead to two undesirable results: 1 ) dispersion of contaminants from stored manure throughout the house, and 2) in cold climates, elevated indoor contaminant levels through the drastic reduction of ventilation to minimize heat loss. Both outcomes may noticeably affect the health of animals and workers.

A new trend to collaborate in the hard work of mitigating emissions in animal buildings may be emerging when designing livestock sheds with low environmental impact. Investments in renewed barns can be associated with innovation and sustainable thinking. The relationship between sustainability and wellbeing issues seems to be a path that highlights the care with the IAQ in animal buildings (Galama et al. 2020) that is certainly worth exploiting.

Summarizing, the type and amount of emissions for any livestock class will be strongly conditioned by 1) the indoor environment; 2) the rearing system applied, mainly the management of the herd and the typology of the shed; and 3) the manure management, especially when stored for a long time inside the building.

These three sets of variables could be analyzed separately to verify their specific impact on the production and level of each type of pollutant. However, all three sets are usually interrelated, and therefore a joint analysis is desirable in order to account for synergies and cancellations. Mitigating solutions for low IAQ in animal buildings should thus be also based on a systemic relational study of the variables considered here.

\section{Abbreviations}

AFO

Animal Feeding Operations

BAT

Best Available Techniques

BREF

Best Available Techniques Reference

$\mathrm{C} / \mathrm{N}$ ratio

Ratio of carbon and nitrogen

$\mathrm{CH}_{4}$

Methane

$\mathrm{CO}_{2}$

Carbon Dioxide 
$\mathrm{CO}_{2} \mathrm{e}$

$\mathrm{CO}_{2}$ equivalent

DON

Deoxynivalenol

E. coli

Escherichia coli

EEA

European Environment Agency

EPA

Environmental Protection Agency

EU

European Union

FAO

Food and Agriculture Organization of the United Nations

GHG

Greenhouse Gas

$\mathrm{H}_{2}$

Hydrogen

$\mathrm{H}_{2} \mathrm{~S}$

Hydrogen sulfide

IAQ

Indoor Air Quality

IED

Industrial Emission Directive

IPCC

Intergovernmental Panel on Climate Change

$\mathrm{N}$

Nitrogen

NO

Nitric oxide

$\mathrm{N}_{2} \mathrm{O}$

Nitrous oxide

$\mathrm{NH}_{3}$

Ammonia

NIV

Nivalenol

PLF

Precision Livestock Farming

PM 
Particulate matter

PPV

Partial Pit Ventilation

$\mathrm{RH}$

Relative air humidity

$\mathrm{SF}_{6}$

Sulfur hexafluoride

$T$

Temperature

US

United States of America

VOC

Volatile Organic Compound

\section{Declarations}

\section{Funding}

The authors declare that no funds, grants, or other support were received during the preparation of this manuscript.

Competing interests

The authors have no relevant financial or non-financial interests to disclose.

Authors' contributions

Idea for the review article: Leonardo de Brito Andrade; César Martín-Gómez

Literature search and data analysis: Leonardo de Brito Andrade; Arturo H. Ariño

Drafted and revised the work: César Martín-Gómez; Amaia Zuazua-Ros; Arturo H. Ariño

Availability of data and material (data transparency)

Nothing to declare.

Code availability (software application or custom code)

Nothing to declare.

Acknowledgements 
The authors would like to thank their respective university centers, the Federal University of Santa Catarina, and the Universidad de Navarra, for encouragement and support.

\section{References}

1. Aatamila M, Verkasalo PK, Korhonen MJ et al (2011) Odour annoyance and physical symptoms among residents living near waste treatment centres. Environ Res 111:164-170. https://doi.org/10.1016/j.envres.2010.11.008

2. Adhikari A, Sen MM, Gupta-Bhattacharya S, Chanda S (2004) Volumetric assessment of airborne fungi in two sections of a rural indoor dairy cattle shed. Environ Int 29:1071-1078. https://doi.org/10.1016/S0160-4120(03)00103-X

3. Ahmed MFM, Schulz J, Hartung J (2013) Survival of Campylobacter jejuni in naturally and artificially contaminated laying hen feces. Poult Sci 92:364-369. https://doi.org/10.3382/ps.2012-02496

4. Akdeniz N, Koziel JA, Glanville TD et al (2011) Air sampling methods for VOCs related to field-scale biosecure swine mortality composting. Bioresour Technol 102:3599-3602. https://doi.org/10.1016/j.biortech.2010.10.100

5. Alberdi $\mathrm{O}$, Arriaga $\mathrm{H}$, Calvet $\mathrm{S}$ et al (2016) Ammonia and greenhouse gas emissions from an enriched cage laying hen facility. Biosyst Eng 144:1-12. https://doi.org/10.1016/j.biosystemseng.2016.01.009

6. Alonso-Moreno C, Garde JJ, Zafrilla JE et al (2018) The Carbon Dioxide-Rumen Fermentation Processes-strategy, a proposal to sustain environmentally friendly dairy farms. J Clean Prod 204:735-743. https://doi.org/https://doi.org/10.1016/j.jclepro.2018.08.295

7. Amon B, Kryvoruchko V, Amon T, Zechmeister-Boltenstern S (2006) Methane, nitrous oxide and ammonia emissions during storage and after application of dairy cattle slurry and influence of slurry treatment. Agric Ecosyst Environ 112:153-162. https://doi.org/10.1016/j.agee.2005.08.030

8. Arogo J, Zhang RH, Riskowski GL et al (1999) Mass Transfer Coefficient of Ammonia in Liquid Swine Manure and Aqueous Solutions. J Agric Eng Res 73:77-86. https://doi.org/10.1006/jaer.1998.0390

9. Arriaga H, Pinto M, Calsamiglia S, Merino P (2009) Nutritional and management strategies on nitrogen and phosphorus use efficiency of lactating dairy cattle on commercial farms: An environmental perspective. J Dairy Sci 92:204-215. https://doi.org/10.3168/jds.2008-1304

10. Banhazi TM, Seedorf J, Laffrique M, Rutley DL (2008) Identification of the risk factors for high airborne particle concentrations in broiler buildings using statistical modelling. Biosyst Eng 101:100-110. https://doi.org/10.1016/j.biosystemseng.2008.06.007

11. Barrasa M, Lamosa S, Fernandez MD, Fernandez E (2012) Occupational exposure to carbon dioxide, ammonia and hydrogen sulphide on livestock farms in north-west Spain. Ann Agric Environ Med 19:17-24

12. Bibbiani C, Russo C (2012) Odour emission from intensive livestock production system: Approaches for emission abatement and evaluation of their effectiveness. Large Anim Rev 18:135-138 
13. Bjerg B, Norton T, Banhazi T et al (2013) Modelling of ammonia emissions from naturally ventilated livestock buildings. Part 1: Ammonia release modelling. Biosyst Eng 116:232-245. https://doi.org/10.1016/j.biosystemseng.2013.08.001

14. Blanes-Vidal V (2015) Air pollution from biodegradable wastes and non-specific health symptoms among residents: Direct or annoyance-mediated associations? Chemosphere 120:371-377. https://doi.org/10.1016/j.chemosphere.2014.07.089

15. Blanes-Vidal V, Hansen MN, Pedersen S, Rom HB (2008) Emissions of ammonia, methane and nitrous oxide from pig houses and slurry: Effects of rooting material, animal activity and ventilation flow. Agric Ecosyst Environ 124:237-244. https://doi.org/https://doi.org/10.1016/j.agee.2007.10.002

16. Blunden J, Aneja VP, Westerman PW (2008) Measurement and analysis of ammonia and hydrogen sulfide emissions from a mechanically ventilated swine confinement building in North Carolina. Atmos Environ 42:3315-3331. https://doi.org/10.1016/j.atmosenv.2007.06.040

17. Bøe KE, Dragsund G, Jørgensen GHM, Fabian-Wheeler E (2017) Air Quality in Norwegian Horse Stables at Low Outdoor Temperatures. J Equine Vet Sci 55:44-50. https://doi.org/10.1016/j.jevs.2017.02.007

18. Bunney PE, Zink AN, Holm AA et al (2017) Orexin activation counteracts decreases in nonexercise activity thermogenesis (NEAT) caused by high-fat diet. Physiol Behav 176:139-148. https://doi.org/10.1016/j.physbeh.2017.03.040

19. Cambra-López M, Aarnink AJA, Zhao Y et al (2010) Airborne particulate matter from livestock production systems: A review of an air pollution problem. Environ Pollut 158:1-17. https://doi.org/10.1016/j.envpol.2009.07.011

20. Cambra-López M, Torres AG, Aarnink AJA, Ogink NWM (2011) Source analysis of fine and coarse particulate matter from livestock houses. Atmos Environ 45:694-707. https://doi.org/10.1016/j.atmosenv.2010.10.018

21. Capelli L, Sironi S, Del Rosso R, Guillot JM (2013) Measuring odours in the environment vs. dispersion modelling: A review. Atmos Environ 79:731-743. https://doi.org/10.1016/j.atmosenv.2013.07.029

22. Carew R (2010) Ammonia emissions from livestock industries in Canada: Feasibility of abatement strategies. Environ Pollut 158:2618-2626. https://doi.org/10.1016/j.envpol.2010.05.004

23. Cederberg C, Sonesson U, Henriksson M et al (2009) Greenhouse gas emissions from Swedish production of meat, milk and eggs 1990 and 2005. Göteborg

24. Chai L, Zhao Y, Xin H et al (2018) Mitigating airborne bacteria generations from cage-free layer litter by spraying acidic electrolysed water. Biosyst Eng 170:61-71. https://doi.org/10.1016/j.biosystemseng.2018.03.013

25. Cheng T, Jiang Y, Xu Y, Zhang Y (2002) Mathematical model for simulation of VOC emissions and concentrations in buildings. Atmos Environ 36:5025-5030. https://doi.org/10.1016/S13522310(02)00572-1 
26. Chung MY, Beene M, Ashkan S et al (2010) Evaluation of non-enteric sources of non-methane volatile organic compound (NMVOC) emissions from dairies. Atmos Environ 44:786-794. https://doi.org/10.1016/j.atmosenv.2009.11.033

27. Clements JM, Pirie RS (2007) Respirable dust concentrations in equine stables. Part 1: Validation of equipment and effect of various management systems. Res Vet Sci 83:256-262. https://doi.org/10.1016/j.rvsc.2006.12.002

28. Conti C, Guarino M, Bacenetti J (2020) Measurements techniques and models to assess odor annoyance: A review. Environ Int 134:105261. https://doi.org/10.1016/j.envint.2019.105261

29. Cornejo C, Wilkie AC (2010) Greenhouse gas emissions and biogas potential from livestock in Ecuador. Energy Sustain Dev 14:256-266. https://doi.org/https://doi.org/10.1016/j.esd.2010.09.008

30. Cortus EL, Jacobson LD, Hetchler BP et al (2015) Methane and nitrous oxide analyzer comparison and emissions from dairy freestall barns with manure flushing and scraping. Atmos Environ 100:5765. https://doi.org/10.1016/j.atmosenv.2014.10.039

31. Costa T, Akdeniz N (2019) A review of the animal disease outbreaks and biosecure animal mortality composting systems. Waste Manag 90:121-131. https://doi.org/10.1016/j.wasman.2019.04.047

32. Costantino A, Fabrizio E, Villagrá A et al (2020) The reduction of gas concentrations in broiler houses through ventilation: Assessment of the thermal and electrical energy consumption. Biosyst Eng. https://doi.org/10.1016/j.biosystemseng.2020.01.002

33. Curtis L, Raymond S, Clarke A (1996) Dust and ammonia in horse stalls with different ventilation rates and bedding. Aerobiologia (Bologna) 12:239-247. https://doi.org/10.1007/BF02248160

34. De Reu K, Grijspeerdt K, Heyndrickx M et al (2005) Bacterial eggshell contamination in conventional cages, furnished cages and aviary housing systems for laying hens. Br Poult Sci 46:149-155. https://doi.org/10.1080/00071660500065359

35. De Reu K, Messens W, Heyndrickx M et al (2008) Bacterial contamination of table eggs and the influence of housing systems. Worlds Poult Sci J 64:5-19.

https://doi.org/10.1017/S0043933907001687

36. Dekker SEM, Aarnink AJA, de Boer IJM, Koerkamp PWGG (2011) Emissions of ammonia, nitrous oxide, and methane from aviaries with organic laying hen husbandry. Biosyst Eng 110:123-133. https://doi.org/https://doi.org/10.1016/j.biosystemseng.2011.07.006

37. Dong H, Zhu Z, Shang B et al (2007) Greenhouse gas emissions from swine barns of various production stages in suburban Beijing, China. Atmos Environ 41:2391-2399. https://doi.org/10.1016/j.atmosenv.2006.11.005

38. Douglas P, Robertson S, Gay R et al (2018) A systematic review of the public health risks of bioaerosols from intensive farming. Int J Hyg Environ Health 221:134-173. https://doi.org/10.1016/j.jijheh.2017.10.019

39. Dueker ME, O'Mullan GD, Weathers KC et al (2012) Coupling of fog and marine microbial content in the near-shore coastal environment. Biogeosciences 9:803-813. https://doi.org/10.5194/bg-9-8032012 
40. Duxbury JM (1994) The significance of agricultural sources of greenhouse gases. Fertil Res 38:151163. https://doi.org/10.1007/BF00748775

41. Ebner MR, Haselwandter K, Frank A (1992) Indoor and outdoor incidence of airborne fungal allergens at low- and high-altitude alpine environments. Mycol Res 96:117-124. https://doi.org/10.1016/S0953-7562(09)80924-6

42. Ecim-Djuric O, Topisirovic G (2010) Energy efficiency optimization of combined ventilation systems in livestock buildings. Energy Build 42:1165-1171. https://doi.org/https://doi.org/10.1016/j.enbuild.2009.10.035

43. EEA (2017) Air quality in Europe

44. EEA (2020) European Environment Agency's home page - European Environment Agency. In: Eur. Environ. Agency. https://www.eea.europa.eu/. Accessed 11 Dec 2020

45. Elfman L, Wlinder R, Miia, Pringle J (2011) Air Quality in Horse Stables. In: Mazzeo N (ed) Chemistry, Emission Control, Radioactive Pollution and Indoor Air Quality. InTech, pp 116-124

46. Ellis CK, Stahl RS, Nol P et al (2014) A pilot study exploring the use of breath analysis to differentiate healthy cattle from cattle experimentally infected with Mycobacterium bovis. PLoS ONE 9:e89280. https://doi.org/10.1371/journal.pone.0089280

47. EPA USEPA (2012) Global Anthropogenic Non-CO2 Greenhouse Gas Emissions: 1990-2030. Washington, DC

48. EPA USEPA (2009) Inventory of U.S. Greenhouse Gas Emissions and Sinks: 1990-2007

49. EPA USEPA (2010) Environmental Mandatory Reporting of Greenhouse Gases: Injection and Geologic Sequestration of Carbon Dioxide. Fed Regist 75:75060-75089

50. EPA USEPA (2008) CERCLA/EPCRA administrative reporting exemption for air releases of hazardous substances from animal waste at farms

51. EPA USEPA (2003) Toxicological Review of Hydrogen Sulfide (CAS No. 7783-06-4)

52. EPA USEPA (2001) Emissions from animal feeding operations

53. EPA USEPA (2004) Risk assessment Evaluation for concentrated animal feeding operations

54. European Commission Publication (2001) Directive 2001/81/EC on national emission ceilings for atmospheric pollutants.Off $\mathrm{J}$ Eur Communities22-30

55. European Commission Publication (2010) Directive 2010/75/EU Industrial Emissions. Off J Eur Union L334:17-119

56. European Commission Publication (2007) Council Directive 2007/43/EC of 28 June 2007 laying down minimum rules for the protection of chickens kept for meat production.Off J Eur Union19-28

57. European Commission Publication (1999) Directive 1999/30/EC of 22 April 1999 relating to limit values for sulphur dioxide, nitrogen dioxide and oxides of nitrogen, particulate matter and lead in ambient air $\mathrm{C}$ directive. Off $\mathrm{J}$ Eur Comm41-60

58. Fabbri C, Valli L, Guarino M et al (2007) Ammonia, methane, nitrous oxide and particulate matter emissions from two different buildings for laying hens. Biosyst Eng 97:441-455. 
https://doi.org/https://doi.org/10.1016/j.biosystemseng.2007.03.036

59. Fang JJ, Yang N, Cen DY et al (2012) Odor compounds from different sources of landfill: Characterization and source identification. Waste Manag 32:1401-1410. https://doi.org/10.1016/j.wasman.2012.02.013

60. FAO (2020) FAOSTAT: Statistics Division. In: Food Agric. Organ. United Nations. http://www.fao.org/faostat/en/\#home. Accessed 1 Dec 2020

61. FAO (2017) The State of Food and Agriculture. Rome

62. FAO (2011) World Livestock 2011 Livestock in food security

63. Fend R, Geddes R, Lesellier S et al (2005) Use of an electronic nose to diagnose Mycobacterium bovis infection in badgers and cattle. J Clin Microbiol 43:1745-1751.

https://doi.org/10.1128/JCM.43.4.1745-1751.2005

64. Filipy J, Rumburg B, Mount $\mathrm{G}$ et al (2006) Identification and quantification of volatile organic compounds from a dairy. Atmos Environ 40:1480-1494.

https://doi.org/10.1016/j.atmosenv.2005.10.048

65. Fleming K, Hessel EF, Van den Weghe HFA (2009) Gas and particle concentrations in horse stables with individual boxes as a function of the bedding material and the mucking regimen 1 . J Anim Sci 87:3805-3816. https://doi.org/10.2527/jas.2008-1569

66. Fleming K, Hessel EF, Van den Weghe HFA (2008) Generation of Airborne Particles from Different Bedding Materials Used for Horse Keeping. J Equine Vet Sci 28:408-418. https://doi.org/10.1016/j.jevs.2008.05.004

67. Fournel S, Pelletier F, Godbout S et al (2011) Greenhouse Gas Emissions from Three Cage Layer Housing Systems. Animals 2:1-15. https://doi.org/10.3390/ani2010001

68. Galama PJ, Ouweltjes W, Endres MI et al (2020) Symposium review: Future of housing for dairy cattle. J Dairy Sci 103:5759-5772. https://doi.org/10.3168/jds.2019-17214

69. Geornaras I, de Jesus AE, van Zyl E, von Holy A (1996) Bacterial populations associated with poultry processing in a South African abattoir. Food Microbiol 13:457-465.

https://doi.org/10.1006/fmic.1996.0052

70. Gerritzen M, Lambooij B, Reimert $\mathrm{H}$ et al (2007) A note on behaviour of poultry exposed to increasing carbon dioxide concentrations. Appl Anim Behav Sci 108:179-185. https://doi.org/10.1016/j.applanim.2006.11.014

71. Giles LV, Koehle MS (2014) The Health Effects of Exercising in Air Pollution. Sport Med 44:223-249. https://doi.org/10.1007/s40279-013-0108-z

72. Gobierno de España (2019) Informe de Inventario Nacional de Gases de Efecto Invernadero (GEI). España, Informe Inventarios GEI 1990-2018 (Edición 2020)

73. Groot Koerkamp PWG (1994) Review on Emissions of Ammonia from Housing Systems for Laying Hens in Relation to Sources, Processes, Building Design and Manure Handling. J Agric Eng Res 59:73-87. https://doi.org/https://doi.org/10.1006/jaer.1994.1065 
74. Groot Koerkamp PWG, Metz JHM, Uenk GH et al (1998) Concentrations and Emissions of Ammonia in Livestock Buildings in Northern Europe. J Agric Eng Res 70:79-95.

https://doi.org/10.1006/jaer.1998.0275

75. Guffanti P, Pifferi V, Falciola L, Ferrante V (2018) Analyses of odours from concentrated animal feeding operations: A review. Atmos Environ 175:100-108. https://doi.org/10.1016/j.atmosenv.2017.12.007

76. Gustafsson G (1999) Factors affecting the Release and Concentration of Dust in Pig Houses. J Agric Eng Res 74:379-390. https://doi.org/10.1006/jaer.1999.0476

77. Gustafsson G, Jeppsson KH, Hultgren J, Sannö JO (2005) Techniques to Reduce the Ammonia Emission from a Cowshed with Tied Dairy Cattle. Agric Eng Int CIGR J VIl:Manuscript BC 04:010

78. Hafner SD, Howard C, Muck RE et al (2013) Emission of volatile organic compounds from silage: Compounds, sources, and implications. Atmos Environ 77:827-839. https://doi.org/10.1016/j.atmosenv.2013.04.076

79. Hallquist $M$, Wenger JC, Baltensperger $U$ et al (2009) The formation, properties and impact of secondary organic aerosol: current and emerging issues. Atmos Chem Phys 9:5155-5236. https://doi.org/10.5194/acp-9-5155-2009

80. Hanhela R, Louhelainen K, Pasanen A-L (1995) Prevalence of microfungi in Finnish cow barns and some aspects of the occurrence of Wallemia sebi and Fusaria. Scand J Work Environ Health 21:223-228. https://doi.org/10.5271/sjweh.31

81. Hannah JF, Wilson JL, Cox NA et al (2011) Comparison of shell bacteria from unwashed and washed table eggs harvested from caged laying hens and cage-free floor-housed laying hens. Poult Sci 90:1586-1593. https://doi.org/10.3382/ps.2010-01115

82. Hansen MJ, Adamsen APS, Jonassen KEN, Feilberg A (2012) The effect of pit ventilation on the emission of odorants from pig production. Chem Eng Trans 30:229-234. https://doi.org/https://doi.org/10.3303/CET1230039

83. Hansen MJ, Kamp JN, Adamsen APS, Feilberg A (2020) Low-emission slurry pits for pig houses with straw application. Biosyst Eng 197:56-63. https://doi.org/10.1016/j.biosystemseng.2020.06.003

84. Hansen MN, Kai P, Moller HB (2006) Effects of anaerobic digestion and separation of pig slurry on odor emission. Appl Eng Agric 22:135-139. https://doi.org/10.13031/2013.20192

85. Harry EG (1978) Air pollution in farm buildings and methods of control: A review. Avian Pathol 7:441-454. https://doi.org/10.1080/03079457808418301

86. Hayes JE, Stevenson RJ, Stuetz RM (2014) The impact of malodour on communities: A review of assessment techniques. Sci Total Environ 500-501:395-407. https://doi.org/10.1016/j.scitotenv.2014.09.003

87. Hellmann B, Zelles L, Palojarvi A, Bai Q (1997) Emission of Climate-Relevant Trace Gases and Succession of Microbial Communities during Open-Windrow Composting. Appl Environ Microbiol 63:1011-1018. https://doi.org/10.1128/AEM.63.3.1011-1018.1997 
88. Herrero B, Zaldivar P (1997) Effects of meteorological factors on the levels of Alternaria and Cladosporium spores in the atmosphere of Palencia, 1990-92. Grana 36:180-184. https://doi.org/10.1080/00173139709362606

89. Herrero M, Henderson B, Havlík P et al (2016) Greenhouse gas mitigation potentials in the livestock sector. Nat Clim Chang 6:452-461. https://doi.org/10.1038/nclimate2925

90. Holcombe SJ, Jackson C, Gerber V et al (2010) Stabling is associated with airway inflammation in young Arabian horses. Equine Vet J 33:244-249. https://doi.org/10.2746/042516401776249606

91. Howard CJ, Kumar A, Malkina I et al (2010) Reactive organic gas emissions from livestock feed contribute significantly to ozone production in central California. Environ Sci Technol 44:2309-2314. https://doi.org/10.1021/es902864u

92. Hu J, Howard CJ, Mitloehner F et al (2012) Mobile source and livestock feed contributions to regional ozone formation in central California. Environ Sci Technol 46:2781-2789. https://doi.org/10.1021/es203369p

93. Huang D, Guo H (2019) Diurnal and seasonal variations of greenhouse gas emissions from a commercial broiler barn and cage-layer barn in the Canadian Prairies. Environ Pollut 248:726-735. https://doi.org/https://doi.org/10.1016/j.envpol.2019.02.065

94. Huijskens EGW, Smit LAM, Rossen JWA et al (2016) Evaluation of Patients with Community-Acquired Pneumonia Caused by Zoonotic Pathogens in an Area with a High Density of Animal Farms. Zoonoses Public Health 63:160-166. https://doi.org/10.1111/zph.12218

95. IPCC (2006) Agriculture, Forestry and Other Land Use. In: Eggleston HS, Buendia L, Miwa K et al (eds) 2006 Intergovernmental Panel on Climate Change (IPCC) Guidelines for National Greenhouse Gas Inventories. IGES, Kanagawa

96. ISO (2008) ISO 5492:2008 - Sensory analysis - Vocabulary

97. Ivester KM, Couëtil LL, Zimmerman NJ (2014) Investigating the Link between Particulate Exposure and Airway Inflammation in the Horse. J Vet Intern Med 28:1653-1665. https://doi.org/10.1111/jvim.12458

98. Ivester KM, Smith K, Moore GE et al (2012) Variability in particulate concentrations in a horse training barn over time. Equine Vet J 44:51-56. https://doi.org/10.1111/j.2042-3306.2012.00647.x

99. Jarvis SC, Pain BF (1994) Greenhouse gas emissions from intensive livestock systems: Their estimation and technologies for reduction. Clim Change 27:27-38. https://doi.org/10.1007/BF01098471

100. Jeppsson K-H (2000) SE-Structure and Environment: Carbon Dioxide Emission and Water Evaporation from Deep Litter Systems. J Agric Eng Res 77:429-440. https://doi.org/10.1006/jaer.2000.0612

101. Jungbluth $T$, Hartung $E$, Brose $G$ (2001) Greenhouse gas emissions from animal houses and manure stores. Nutr Cycl Agroecosystems 60:133-145. https://doi.org/10.1023/A:1012621627268

102. Kaiser E-A, Eiland F, Germon JC et al (1996) What predicts nitrous oxide emissions and denitrification N-loss from European soils? Z für Pflanzenernährung und Bodenkd 159:541-547. 
https://doi.org/10.1002/jpln.1996.3581590604

103. Kandylis K (1984) Toxicology of Sulfur in Ruminants: Review. J Dairy Sci 67:2179-2187. https://doi.org/https://doi.org/10.3168/jds.S0022-0302(84)81564-7

104. Katayama Y, Oikawa M, Yoshihara T et al (1995) Clinico-Pathological Effects of Atmospheric Ammonia Exposure on Horses. J Equine Sci 6:99-104. https://doi.org/10.1294/jes.6.99

105. Kebreab E, Clark K, Wagner-Riddle C, France J (2006) Methane and nitrous oxide emissions from Canadian animal agriculture: A review. Can J Anim Sci 86:135-157. https://doi.org/10.4141/A05010

106. Keck M, Mager K, Weber K et al (2018) Odour impact from farms with animal husbandry and biogas facilities. Sci Total Environ 645:1432-1443. https://doi.org/10.1016/j.scitotenv.2018.07.182

107. Khan RZ, Müller C, Sommer SG (1997) Micrometeorological mass balance technique for measuring $\mathrm{CH} 4$ emission from stored cattle slurry. Biol Fertil Soils 24:442-444. https://doi.org/10.1007/s003740050270

108. Kim KY, Ko HJ, Lee KJ et al (2005) Temporal and spatial distributions of aerial contaminants in an enclosed pig building in winter. Environ Res 99:150-157. https://doi.org/10.1016/j.envres.2004.10.004

109. Koinakis CJ (2005) Combined thermal and natural ventilation modeling for long-term energy assessment: validation with experimental measurements. Energy Build 37:311-323. https://doi.org/https://doi.org/10.1016/j.enbuild.2004.06.022

110. Komilis DP, Ham RK, Park JK (2004) Emission of volatile organic compounds during composting of municipal solid wastes. Water Res 38:1707-1714. https://doi.org/10.1016/j.watres.2003.12.039

111. Kristensen HH, Burgess LR, Demmers TGH, Wathes CM (2000) The preferences of laying hens for different concentrations of atmospheric ammonia. Appl Anim Behav Sci 68:307-318. https://doi.org/10.1016/S0168-1591(00)00110-6

112. Kumanan V, Nugen SR, Baeumner AJ, Chang YF (2009) A biosensor assay for the detection of Mycobacterium avium subsp. paratuberculosis in fecal samples. J Vet Sci 10:35-42. https://doi.org/10.4142/jvs.2009.10.1.35

113. Kumari S, Fagodiya RK, Hiloidhari M et al (2020) Methane production and estimation from livestock husbandry: A mechanistic understanding and emerging mitigation options. Sci Total Environ 709:136135. https://doi.org/10.1016/j.scitotenv.2019.136135

114. Kwiatkowska-Stenzel A, Sowińska J, Witkowska D (2014) Analysis of Noxious Gas Pollution in Horse Stable Air. J Equine Vet Sci 34:249-256. https://doi.org/10.1016/j.jevs.2013.05.006

115. Lee C, Morris DL, Lefever KM, Dieter PA (2020) Feeding a diet with corn distiller grains with solubles to dairy cows alters manure characteristics and ammonia and hydrogen sulfide emissions from manure. J Dairy Sci 103:2363-2372. https://doi.org/10.3168/jds.2019-17524

116. Lee SA, Liao CH (2014) Size-selective assessment of agricultural workers' personal exposure to airborne fungi and fungal fragments. Sci Total Environ 466-467:725-732. https://doi.org/10.1016/j.scitotenv.2013.07.104 
117. Leip A, Billen G, Garnier J et al (2015) Impacts of European livestock production: nitrogen, sulphur, phosphorus and greenhouse gas emissions, land-use, water eutrophication and biodiversity. Environ Res Lett 10:1-13. https://doi.org/10.1088/1748-9326/10/11/115004

118. Lesschen JP, van den Berg M, Westhoek HJ et al (2011) Greenhouse gas emission profiles of European livestock sectors. Anim Feed Sci Technol 166-167:16-28. https://doi.org/https://doi.org/10.1016/j.anifeedsci.2011.04.058

119. Liang L, Lal R, Du Z et al (2013) Estimation of nitrous oxide and methane emission from livestock of urban agriculture in Beijing. Agric Ecosyst Environ 170:28-35. https://doi.org/https://doi.org/10.1016/j.agee.2013.02.005

120. Liang $Y$, Xin H, Wheeler EF et al (2005) Ammonia emissions from U.S. laying hen houses in lowa and Pennsylvania. Trans ASAE 48:1927-1941. https://doi.org/10.13031/2013.20002

121. Lues JFR, Theron MM, Venter P, Rasephei MHR (2007) Microbial Composition in Bioaerosols of a High-Throughput Chicken-Slaughtering Facility. Poult Sci 86:142-149. https://doi.org/10.1093/ps/86.1.142

122. Mallin MA, Mclver MR, Robuck AR, Dickens AK (2015) Industrial Swine and Poultry Production Causes Chronic Nutrient and Fecal Microbial Stream Pollution. Water Air Soil Pollut 226:407. https://doi.org/10.1007/s11270-015-2669-y

123. Malone Rubright SL, Pearce LL, Peterson J (2017) Environmental toxicology of hydrogen sulfide. Nitric Oxide 71:1-13. https://doi.org/10.1016/j.niox.2017.09.011

124. Martin RS, Silva PJ, Moore K et al (2008) Particle composition and size distributions in and around a deep-pit swine operation, Ames, IA. J Atmos Chem 59:135-150. https://doi.org/10.1007/s10874008-9097-y

125. Mathot M, Decruyenaere V, Stilmant D, Lambert R (2012) Effect of cattle diet and manure storage conditions on carbon dioxide, methane and nitrous oxide emissions from tie-stall barns and stored solid manure. Agric Ecosyst Environ 148:134-144. https://doi.org/10.1016/j.agee.2011.11.012

126. McGovern RH, Feddes JJR, Zuidhof MJ et al (2001) Growth performance, heart characteristics and the incidence of ascites in broilers in response to carbon dioxide and oxygen concentrations. Can Biosyst Eng / Le Genie des Biosyst au Canada 43:41-46. https://doi.org/10.7939/R3319SG48

127. Méda B, Hassouna M, Lecomte $M$ et al (2015) Influence of season and outdoor run characteristics on excretion behaviour of organic broilers and gaseous emissions. Biosyst Eng 139:35-47. https://doi.org/10.1016/j.biosystemseng.2015.08.001

128. Merino $\mathrm{P}$, Ramirez-Fanlo E, Arriaga $\mathrm{H}$ et al (2011) Regional inventory of methane and nitrous oxide emission from ruminant livestock in the Basque Country. Anim Feed Sci Technol 166-167:628-640. https://doi.org/10.1016/j.anifeedsci.2011.04.081

129. Millerick-May ML, Karmaus W, Derksen FJ et al (2015) Airborne particulates (PM10) and tracheal mucus: A case-control study at an American Thoroughbred racetrack. Equine Vet J 47:410-414. https://doi.org/10.1111/evj.12303 
130. Monks PS, Granier C, Fuzzi S et al (2009) Atmospheric composition change - global and regional air quality. Atmos Environ 43:5268-5350. https://doi.org/10.1016/j.atmosenv.2009.08.021

131. Monteny GJ, Bannink A, Chadwick D (2006) Greenhouse gas abatement strategies for animal husbandry. Agric Ecosyst Environ 112:163-170. https://doi.org/10.1016/j.agee.2005.08.015

132. Monteny GJ, Groenestein CM, Hilhorst MA (2001) Interactions and coupling between emissions of methane and nitrous oxide from animal husbandry. Nutr Cycl Agroecosystems 60:123-132. https://doi.org/https://doi.org/10.1023/A:1012602911339

133. Mosier AR (1994) Nitrous oxide emissions from agricultural soils. Fertil Res 37:191-200. https://doi.org/10.1007/BF00748937

134. Mosquera J, Monteny GJ, Erisman JW (2005) Overview and assessment of techniques to measure ammonia emissions from animal houses: the case of the Netherlands. Environ Pollut 135:381-388. https://doi.org/10.1016/j.envpol.2004.11.011

135. Moss AR, Jouany J-P, Newbold J (2000) Methane production by ruminants: its contribution to global warming. Ann Zootech 49:231-253. https://doi.org/10.1051/animres:2000119

136. Mostafa E, Buescher W (2011) Indoor air quality improvement from particle matters for laying hen poultry houses. Biosyst Eng 109:22-36. https://doi.org/10.1016/j.biosystemseng.2011.01.011

137. Mostafa E, Hoelscher R, Diekmann B et al (2017) Evaluation of two indoor air pollution abatement techniques in forced-ventilation fattening pig barns. Atmos Pollut Res 8:428-438. https://doi.org/10.1016/j.apr.2016.11.003

138. Mostafa E, Nannen C, Henseler J et al (2016) Physical properties of particulate matter from animal houses-empirical studies to improve emission modelling. Environ Sci Pollut Res 23:12253-12263. https://doi.org/10.1007/s11356-016-6424-8

139. Nannen C, Bonn WB (2006) Effect of animal activity on dust release and particle emissions: investigations in pig fattening houses. Landtechnik 61:36-37. https://doi.org/https://doi.org/10.15150/lt.2006.1048

140. Nazarenko Y, Westendorf ML, Williams CA, Mainelis G (2018) The Effects of Bedding Type in Stalls and Activity of Horses on Stall Air Quality. J Equine Vet Sci 67:91-98. https://doi.org/10.1016/j.jevs.2018.03.014

141. Ngwabie NM, Jeppsson K-H, Gustafsson G, Nimmermark S (2011) Effects of animal activity and air temperature on methane and ammonia emissions from a naturally ventilated building for dairy cows. Atmos Environ 45:6760-6768. https://doi.org/10.1016/j.atmosenv.2011.08.027

142. Ngwabie NM, Jeppsson K-H, Nimmermark S et al (2009) Multi-location measurements of greenhouse gases and emission rates of methane and ammonia from a naturally-ventilated barn for dairy cows. Biosyst Eng 103:68-77. https://doi.org/10.1016/j.biosystemseng.2009.02.004

143. Ni J-Q (2015) Research and demonstration to improve air quality for the U.S. animal feeding operations in the 21st century - A critical review. Environ Pollut 200:105-119. https://doi.org/10.1016/j.envpol.2015.02.003 
144. Ni J-Q, Chai L, Chen L et al (2012a) Characteristics of ammonia, hydrogen sulfide, carbon dioxide, and particulate matter concentrations in high-rise and manure-belt layer hen houses. Atmos Environ 57:165-174. https://doi.org/10.1016/j.atmosenv.2012.04.023

145. Ni J-Q, Erasmus MA, Croney CC et al (2021) A critical review of advancement in scientific research on food animal welfare-related air pollution. J Hazard Mater 408:124468. https://doi.org/10.1016/j.jhazmat.2020.124468

146. Ni J-Q, Heber AJ (2010) An on-site computer system for comprehensive agricultural air quality research. Comput Electron Agric 71:38-49. https://doi.org/10.1016/j.compag.2009.12.001

147. Ni J-Q, Liu S, Diehl CA et al (2017) Emission factors and characteristics of ammonia, hydrogen sulfide, carbon dioxide, and particulate matter at two high-rise layer hen houses. Atmos Environ 154:260-273. https://doi.org/10.1016/j.atmosenv.2017.01.050

148. Ni J-Q, Robarge WP, Xiao C, Heber AJ (2012b) Volatile organic compounds at swine facilities: A critical review. Chemosphere 89:769-788. https://doi.org/10.1016/j.chemosphere.2012.04.061

149. Nicholson FA, Chambers BJ, Walker AW (2004) Ammonia Emissions from Broiler Litter and Laying Hen Manure Management Systems. Biosyst Eng 89:175-185. https://doi.org/10.1016/j.biosystemseng.2004.06.006

150. Nimmermark S, Gustafsson G (2005) Influence of Temperature, Humidity and Ventilation Rate on the Release of Odour and Ammonia in a Floor Housing System for Laying Hens. Agric Eng Int CIGR Ejournal VII:Manuscript BC 04:008

151. Nimmermark S, Lund V, Gustafsson G, Eduard W (2009) Ammonia, dust, and bacteria in welfareoriented systems for laying hens. Ann Agric Environ Med AAEM 16:103-113

152. NRC (2009) Emergency and Continuous Exposure Guidance Levels for Selected Submarine Contaminants: Volume 3 Committee on Emergency and Continuous Exposure Guidance Levels for Selected. Submarine Contaminants; Committee on Toxicology; National Research Council, Washington (DC)

153. NRC (2003) Air Emissions from Animal Feeding Operations: Current Knowledge, Future Needs. National Academies Press, Washington, D.C.

154. O'Shaughnessy PT, Achutan C, Karsten AW (2002) Temporal Variation of Indoor Air Quality in an Enclosed Swine Confinement Building. J Agric Saf Health 8:349-364. https://doi.org/10.13031/2013.10217

155. Oenema O, Oudendag D, Velthof GL (2007) Nutrient losses from manure management in the European Union. Livest Sci 112:261-272. https://doi.org/10.1016/j.livsci.2007.09.007

156. Olanrewaju HA III, Purswell WAD et al (2008) Growth Performance and Physiological Variables for Broiler Chickens Subjected to Short-Term Elevated Carbon Dioxide Concentrations. Int J Poult Sci 7:738-742. https://doi.org/10.3923/ijps.2008.738.742

157. Olesen JE, Schelde K, Weiske A et al (2006) Modelling greenhouse gas emissions from European conventional and organic dairy farms. Agric Ecosyst Environ 112:207-220. https://doi.org/https://doi.org/10.1016/j.agee.2005.08.022 
158. Olivier JGJ, Bouwman AF, Van der Hoek KW, Berdowski JJM (1998) Global air emission inventories for anthropogenic sources of NOx, NH3 and N2O in 1990. Environ Pollut 102:135-148. https://doi.org/https://doi.org/10.1016/S0269-7491(98)80026-2

159. Orzi V, Riva C, Scaglia B et al (2018) Anaerobic digestion coupled with digestate injection reduced odour emissions from soil during manure distribution. Sci Total Environ 621:168-176. https://doi.org/https://doi.org/10.1016/j.scitotenv.2017.11.249

160. Palmiotto M, Fattore $E$, Paiano V et al (2014) Influence of a municipal solid waste landfill in the surrounding environment: Toxicological risk and odor nuisance effects. Environ Int 68:16-24. https://doi.org/10.1016/j.envint.2014.03.004

161. Park J, Kang T, Heo Y et al (2019) Evaluation of Short-Term Exposure Levels on Ammonia and Hydrogen Sulfide During Manure-Handling Processes at Livestock Farms. https://doi.org/10.1016/j.shaw.2019.12.007. Saf Health Work

162. Peled N, lonescu R, Nol P et al (2012) Detection of volatile organic compounds in cattle naturally infected with Mycobacterium bovis. Sens Actuators B Chem 171-172:588-594. https://doi.org/10.1016/j.snb.2012.05.038

163. Pereira JLS, Ferreira S, Pinheiro V, Trindade H (2018) Ammonia, Nitrous Oxide, Carbon Dioxide and Methane Emissions from Commercial Broiler Houses in Mediterranean Portugal. Water Air Soil Pollut 229:377. https://doi.org/10.1007/s11270-018-4026-4

164. Philippe F-X, Nicks B (2015) Review on greenhouse gas emissions from pig houses: Production of carbon dioxide, methane and nitrous oxide by animals and manure. Agric Ecosyst Environ 199:1025. https://doi.org/10.1016/j.agee.2014.08.015

165. Popescu S, Stefan R, Borda C et al (2010) The ammonia concentration in growing-finishing pig houses. Lucr Stiint Med Vet VOL XLIII(2) XLIII:320-326

166. Puma MC, Maghirang RG (2000) A Macroscopic Model for Predicting Dust Concentration Distribution in Swine Buildings. Indoor Built Environ 9:182-191. https://doi.org/10.1159/000057506

167. Quarles CL, Gentry RF, Bressler GO (1970) Bacterial Contamination in Poultry Houses and its Relationship to Egg Hatchability. Poult Sci 49:60-66. https://doi.org/10.3382/ps.0490060

168. Ramankutty N, Mehrabi Z, Waha K et al (2018) Trends in Global Agricultural Land Use: Implications for Environmental Health and Food Security. Annu Rev Plant Biol 69:789-815. https://doi.org/10.1146/annurev-arplant-042817-040256

169. Richardson CM, Baes CF, Amer PR et al (2020) Estimating the environmental impact of dairy cattle breeding programs through emission intensity. Animal 100005. https://doi.org/10.1016/j.animal.2020.100005

170. Rong L, Liu D, Pedersen EF, Zhang G (2014) Effect of climate parameters on air exchange rate and ammonia and methane emissions from a hybrid ventilated dairy cow building. Energy Build 82:632643. https://doi.org/10.1016/j.enbuild.2014.07.089

171. Rong L, Nielsen PV, Zhang G (2009) Effects of airflow and liquid temperature on ammonia mass transfer above an emission surface: Experimental study on emission rate. Bioresour Technol 
100:4654-4661. https://doi.org/10.1016/j.biortech.2009.05.003

172. Rotz CA (2018) Modeling greenhouse gas emissions from dairy farms. J Dairy Sci 101:6675-6690. https://doi.org/10.3168/jds.2017-13272

173. Rundell KW (2012) Effect of air pollution on athlete health and performance. Br J Sports Med 46:407-412. https://doi.org/10.1136/bjsports-2011-090823

174. Rylander R, Carvalheiro MF (2006) Airways inflammation among workers in poultry houses. Int Arch Occup Environ Health 79:487-490. https://doi.org/10.1007/s00420-005-0072-5

175. Saha CK, Zhang G, Kai P, Bjerg B (2010) Effects of a partial pit ventilation system on indoor air quality and ammonia emission from a fattening pig room. Biosyst Eng 105:279-287. https://doi.org/10.1016/j.biosystemseng.2009.11.006

176. Saha CK, Zhang G, Ni J-Q, Ye Z (2011) Similarity criteria for estimating gas emission from scale models. Biosyst Eng 108:227-236. https://doi.org/10.1016/j.biosystemseng.2010.12.005

177. Schneider FE, Engelhardt T, Wieser PH (2001) Characterization of Aerosol Particles from Animal Husbandry with Single Particle Analytic Techniques. In: ASAE The Society for Engineering in Agricultural F and BS (ed) 2001 ASAE Annual International Meeting. Sacramento, pp 1-11

178. Schulze T, Eicker U (2013) Controlled natural ventilation for energy efficient buildings. Energy Build 56:221-232. https://doi.org/https://doi.org/10.1016/j.enbuild.2012.07.044

179. Sebacher DI, Harriss RC, Bartlett KB (1983) Methane flux across the air-water interface: air velocity effects. Tellus B Chem Phys Meteorol 35:103-109. https://doi.org/10.3402/tellusb.v35i2.14790

180. Seedorf J, Hartung J (1999) Survey of ammonia concentrations in livestock buildings. J Agric Sci 133:433-437. https://doi.org/10.1017/S0021859699007170

181. Seedorf J, Hartung J, Schröder M et al (1998) Concentrations and Emissions of Airborne Endotoxins and Microorganisms in Livestock Buildings in Northern Europe. J Agric Eng Res 70:97-109. https://doi.org/10.1006/jaer.1997.0281

182. Shen D, Wu S, Li Z et al (2019) Distribution and physicochemical properties of particulate matter in swine confinement barns. Environ Pollut 250:746-753.

https://doi.org/10.1016/j.envpol.2019.04.086

183. Shepherd TA, Zhao Y, Li H et al (2015) Environmental assessment of three egg production systems Part II. Ammonia, greenhouse gas, and particulate matter emissions. Poult Sci 94:534-543. https://doi.org/10.3382/ps/peu075

184. Shirasu M, Touhara K (2011) The scent of disease: Volatile organic compounds of the human body related to disease and disorder. J Biochem 150:257-266. https://doi.org/10.1093/jb/mvr090

185. Smets W, Moretti S, Denys S, Lebeer S (2016) Airborne bacteria in the atmosphere: Presence, purpose, and potential. Atmos Environ 139:214-221.

https://doi.org/10.1016/j.atmosenv.2016.05.038

186. Solomon S, Qin D, Manning M et al (2007) Climate Change 2007: The Physical Science Basis. Contribution of Working Group I to the Fourth Assessment Report of the Intergovernmental Panel on 
Climate Change

187. Soupir ML, Mostaghimi S, Yagow ER et al (2006) Transport Of Fecal Bacteria From Poultry Litter and Cattle Manures Applied to Pastureland. Water Air Soil Pollut 169:125-136. https://doi.org/10.1007/s11270-006-1808-x

188. Starmans D, Van der Hoek K (2007) Ammonia the case of The Netherlands. Wageningen Academic Publishers, The Netherlands

189. Stetzenbach LD, Buttner MP, Cruz P (2004) Detection and enumeration of airborne biocontaminants. Curr Opin Biotechnol 15:170-174. https://doi.org/10.1016/j.copbio.2004.04.009

190. Stinn JP, Xin H, Shepherd TA et al (2014) Ammonia and greenhouse gas emissions from a modern U.S. swine breeding-gestation-farrowing system. Atmos Environ 98:620-628. https://doi.org/10.1016/j.atmosenv.2014.09.037

191. Sun F, Dai Y, Yu X (2017) Air pollution, food production and food security: A review from the perspective of food system. J Integr Agric 16:2945-2962. https://doi.org/10.1016/S20953119(17)61814-8

192. Takahashi T (1997) Airborne fungal colony-forming units in outdoor and indoor environments in Yokohama, Japan. Mycopathologia 139:23-33. https://doi.org/10.1023/A:1006831111595

193. Takai H, Nimmermark S, Banhazi T et al (2013) Airborne pollutant emissions from naturally ventilated buildings: Proposed research directions. Biosyst Eng 116:214-220. https://doi.org/10.1016/j.biosystemseng.2012.12.015

194. Trabue S, Kerr B, Bearson B, Ziemer C (2011) Swine Odor Analyzed by Odor Panels and Chemical Techniques. J Environ Qual 40:1510-1520. https://doi.org/10.2134/jeq2010.0522

195. Tullo E, Finzi A, Guarino M (2019) Review: Environmental impact of livestock farming and Precision Livestock Farming as a mitigation strategy. Sci Total Environ 650:2751-2760. https://doi.org/10.1016/j.scitotenv.2018.10.018

196. Ulens T, Millet S, Van Ransbeeck N et al (2014) The effect of different pen cleaning techniques and housing systems on indoor concentrations of particulate matter, ammonia and greenhouse gases (CO2, CH4, N2O). Livest Sci 159:123-132. https://doi.org/10.1016/j.livsci.2013.10.024

197. Van Amstel AR, Swart RJ (1994) Methane and nitrous oxide emissions: an introduction. Fertil Res 37:213-225. https://doi.org/10.1007/BF00748940

198. Van Ransbeeck N, Van Langenhove H, Demeyer P (2013) Indoor concentrations and emissions factors of particulate matter, ammonia and greenhouse gases for pig fattening facilities. Biosyst Eng 116:518-528. https://doi.org/10.1016/j.biosystemseng.2013.10.010

199. Van Ransbeeck N, Van Langenhove H, Van Weyenberg S et al (2012) Typical indoor concentrations and emission rates of particulate matter at building level: A case study to setup a measuring strategy for pig fattening facilities. Biosyst Eng 111:280-289.

https://doi.org/10.1016/j.biosystemseng.2011.12.004

200. Vandenput S, Istasse L, Nicks B, Lekeux P (1997) Airborne dust and aeroallergen concentrations in different sources of feed and bedding for horses. Vet Q 19:154-158. 
https://doi.org/10.1080/01652176.1997.9694762

201. Vergé XPC, Dyer JA, Desjardins RL, Worth D (2009) Long-term trends in greenhouse gas emissions from the Canadian poultry industry. J Appl Poult Res 18:210-222. https://doi.org/https://doi.org/10.3382/japr.2008-00091

202. Vuèemilo M, Vinkoviæ B, Matkoviæ K et al (2010) The influence of housing systems on the air quality and bacterial eggshell contamination of table eggs. Czech J Anim Sci 55:243-249. https://doi.org/10.17221/64/2009-CJAS

203. Wales A, Breslin M, Davies R (2006) Assessment of cleaning and disinfection in Salmonellacontaminated poultry layer houses using qualitative and semi-quantitative culture techniques. Vet Microbiol 116:283-293. https://doi.org/10.1016/j.vetmic.2006.04.026

204. Wålinder R, Riihimäki M, Bohlin S et al (2011) Installation of mechanical ventilation in a horse stable: effects on air quality and human and equine airways. Environ Health Prev Med 16:264-272. https://doi.org/10.1007/s12199-010-0195-5

205. Wang-Li L, Li Q, Byfield GE (2013) Identification of Bioaerosols Released from an Egg Production Facility in the Southeast United States. Environ Eng Sci 30:2-10. https://doi.org/10.1089/ees.2011.0517

206. Wang K, Wei B, Zhu S, Ye Z (2011) Ammonia and odour emitted from deep litter and fully slatted floor systems for growing-finishing pigs. Biosyst Eng 109:203-210. https://doi.org/10.1016/j.biosystemseng.2011.04.001

207. Wang X, Zhang Y, Riskowski GL, Ellis M (2002) SE-Structures and Environment: Measurement and Analysis of Dust Spatial Distribution in a Mechanically Ventilated Pig Building. Biosyst Eng 81:225236. https://doi.org/10.1006/bioe.2001.0014

208. Wang Y-C, Han M-F, Jia T-P et al (2021) Emissions, measurement, and control of odor in livestock farms: A review. Sci Total Environ 776:145735. https://doi.org/10.1016/j.scitotenv.2021.145735

209. Watt AC, Aziz SM, Banhazi TM (2010) Air Pollution and Livestock Production.XVIlth World Congr Int Comm Agric Biosyst Eng1-10

210. Webb J, Menzi H, Pain BF et al (2005) Managing ammonia emissions from livestock production in Europe. Environ Pollut 135:399-406. https://doi.org/10.1016/j.envpol.2004.11.013

211. Webb J, Sommer SG, Kupper T et al (2012) Emissions of Ammonia, Nitrous Oxide and Methane During the Management of Solid Manures. In: Lichtfouse E (ed) Agroecology and Strategies for Climate Change. Springer Netherlands, Dordrecht, pp 67-107

212. Weiske A, Vabitsch A, Olesen JE et al (2006) Mitigation of greenhouse gas emissions in European conventional and organic dairy farming. Agric Ecosyst Environ 112:221-232.

https://doi.org/https://doi.org/10.1016/j.agee.2005.08.023

213. WHO (1990) Selected mycotoxins: ochratoxins, trichothecenes, ergot

214. WHO (2013) Health Effects of Particulate Matter 
215. Whyte P, Collins JD, McGill K et al (2001) Distribution and Prevalence of Airborne Microorganisms in Three Commercial Poultry Processing Plants. J Food Prot 64:388-391.

https://doi.org/10.4315/0362-028X-64.3.388

216. Wolter M, Prayitno S, Schuchardt F (2004) Greenhouse gas emission during storage of pig manure on a pilot scale. Bioresour Technol 95:235-244. https://doi.org/10.1016/j.biortech.2003.01.003

217. Wu W, Kai P, Zhang G (2012a) An assessment of a partial pit ventilation system to reduce emission under slatted floor - Part 1: Scale model study. Comput Electron Agric 83:127-133.

https://doi.org/https://doi.org/10.1016/j.compag.2012.01.008

218. Wu W, Zhang G, Bjerg B, Nielsen PV (2012b) An assessment of a partial pit ventilation system to reduce emission under slatted floor - Part 2: Feasibility of CFD prediction using RANS turbulence models. Comput Electron Agric 83:134-142.

https://doi.org/https://doi.org/10.1016/j.compag.2012.01.011

219. Xie Q, Ni J-Q, Su Z (2017) Fuzzy comprehensive evaluation of multiple environmental factors for swine building assessment and control. J Hazard Mater 340:463-471.

https://doi.org/10.1016/j.jhazmat.2017.07.024

220. Xin H, Gates RS, Green AR et al (2011) Environmental impacts and sustainability of egg production systems. Poult Sci 90:263-277. https://doi.org/10.3382/ps.2010-00877

221. Xu W, Zheng K, Meng L et al (2017) Concentrations and Emissions of Particulate Matter from Intensive Pig Production at a Large Farm in North China. Aerosol Air Qual Res 16:79-90. https://doi.org/10.4209/aaqr.2015.02.0078

222. Yao Q, Yang Z, Li H et al (2018) Assessment of particulate matter and ammonia emission concentrations and respective plume profiles from a commercial poultry house. Environ Pollut 238:10-16. https://doi.org/10.1016/j.envpol.2018.02.039

223. Ye Z, Zhang G, Li B et al (2008) Ammonia Emissions Affected by Airflow in a Model Pig House: Effects of Ventilation Rate, Floor Slat Opening, and Headspace Height in a Manure Storage Pit. Trans ASABE 51:2113-2122. https://doi.org/10.13031/2013.25393

224. Young P, Price L, Berckmans D, Janssens K (2000) Recent developments in the modelling of imperfectly mixed airspaces. Comput Electron Agric 26:239-254. https://doi.org/10.1016/S01681699(00)00078-8

225. Zhai Y, Li X, Wang T et al (2018) A review on airborne microorganisms in particulate matters: Composition, characteristics and influence factors. Environ Int 113:74-90. https://doi.org/10.1016/j.envint.2018.01.007

226. Zhao Y, Aarnink AJA, De Jong MCM, Groot Koerkamp PWG (2014) Airborne Microorganisms From Livestock Production Systems and Their Relation to Dust. Crit Rev Environ Sci Technol 44:10711128. https://doi.org/10.1080/10643389.2012.746064

227. Zhao Y, Shepherd TA, Li H, Xin H (2015) Environmental assessment of three egg production systems-Part I: Monitoring system and indoor air quality. Poult Sci 94:518-533. https://doi.org/10.3382/ps/peu076 
228. Zhao Y, Zhao D, Ma H et al (2016) Environmental assessment of three egg production systems Part III: Airborne bacteria concentrations and emissions. Poult Sci 95:1473-1481.

https://doi.org/10.3382/ps/pew053

229. Zhu Z, Dong H, Zhou Z et al (2011) Ammonia and Greenhouse Gases Concentrations and Emissions of a Naturally Ventilated Laying Hen House in Northeast China. Trans ASABE 54:1085-1091. https://doi.org/https://doi.org/10.13031/2013.37100

230. Zong C, Li H, Zhang G (2015) Ammonia and greenhouse gas emissions from fattening pig house with two types of partial pit ventilation systems. Agric Ecosyst Environ 208:94-105. https://doi.org/https://doi.org/10.1016/j.agee.2015.04.031

231. Zucker B-A, Trojan S, Muller W (2000) Airborne Gram-Negative Bacterial Flora in Animal Houses. J Vet Med Ser B 47:37-46. https://doi.org/10.1046/j.1439-0450.2000.00308.x

\section{Figures}

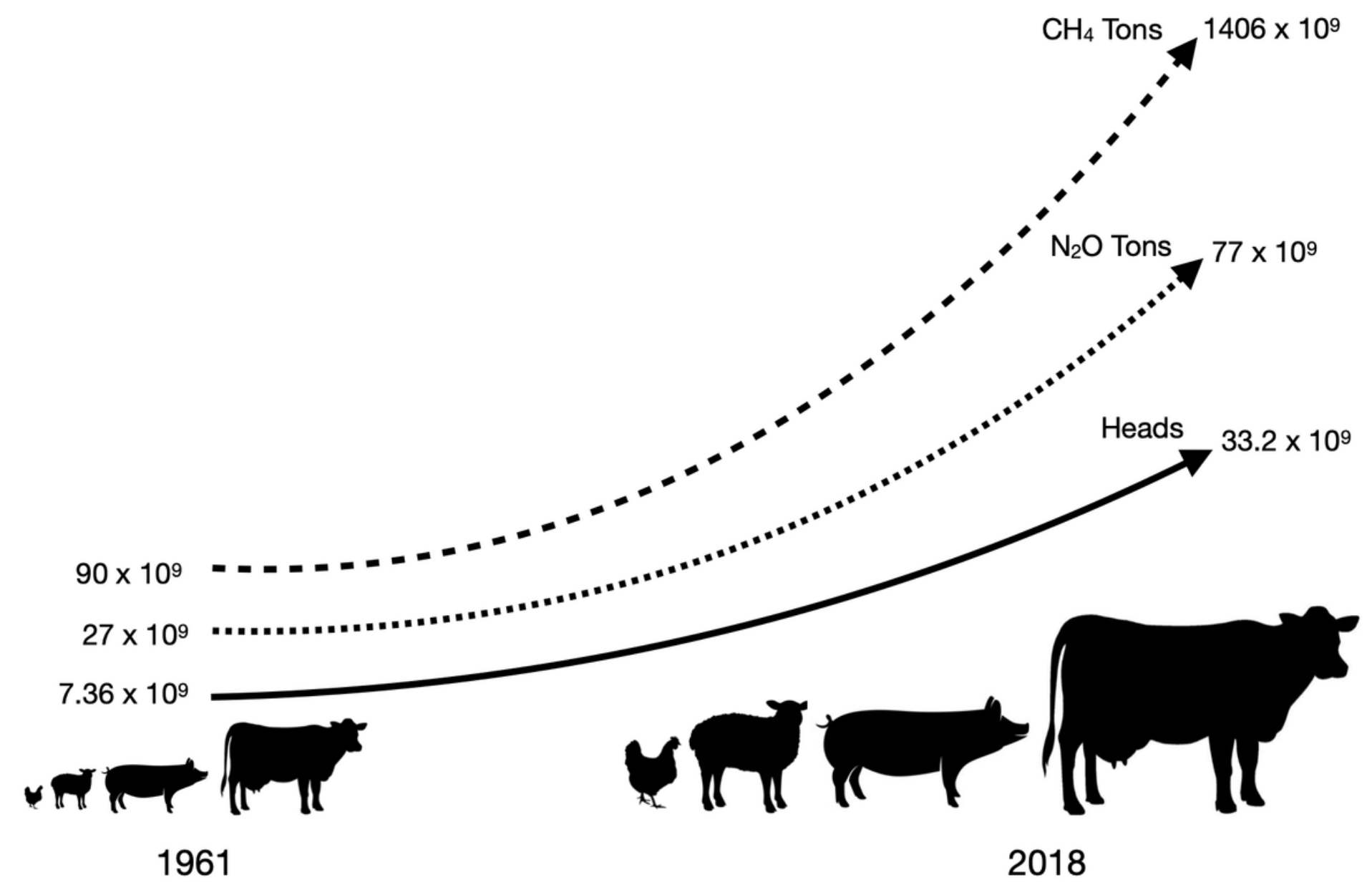

Figure 1

Evolution of production and animal GHG impact in the last 47 years (FAO 2020) 


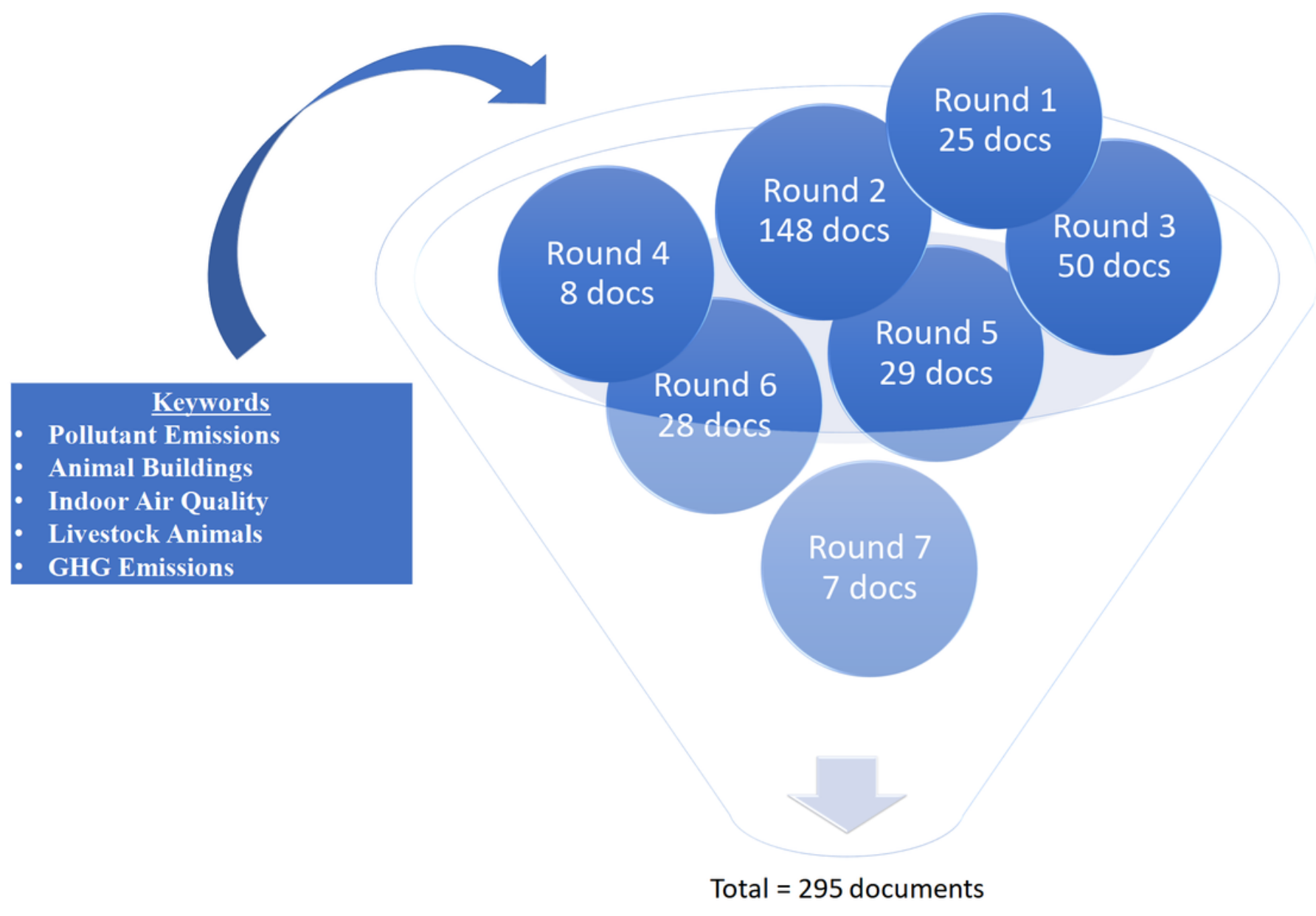

\section{Figure 2}

Rounds of literature review 
70

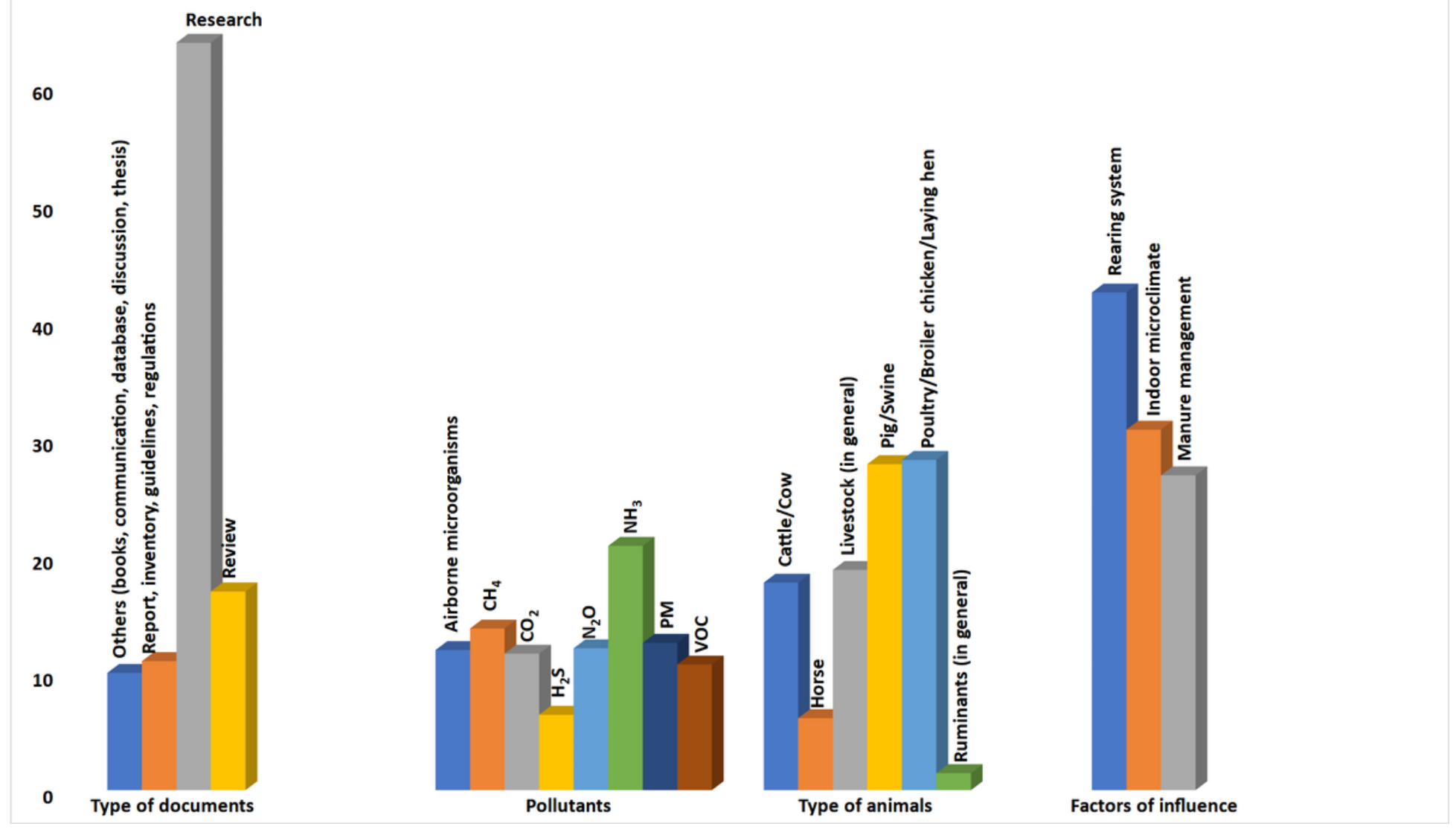

Figure 3

Breakdown of the selected articles according to the type of document, the pollutants considered/researched, the animals studied, and the factor of influence considered 


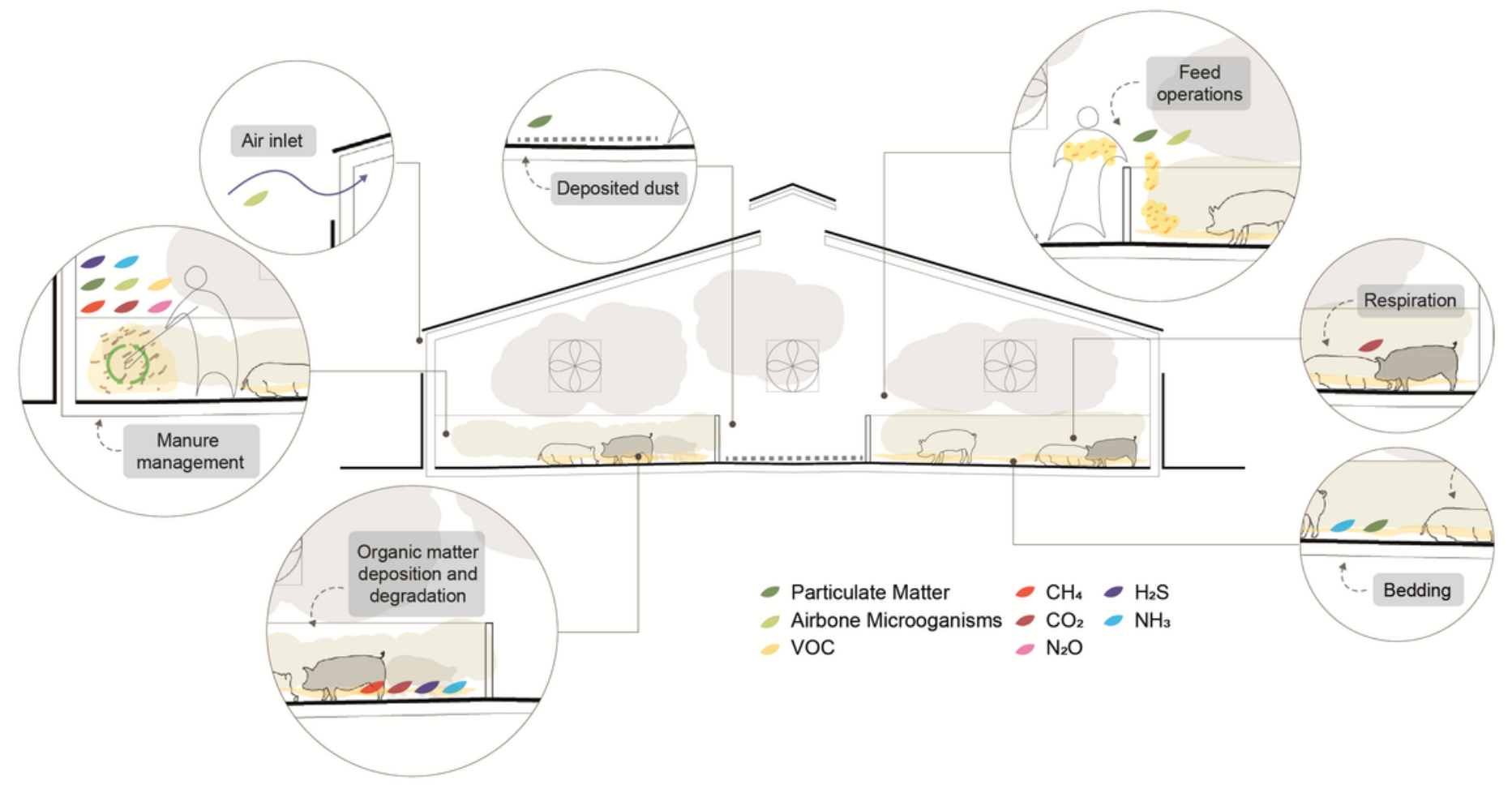

Figure 4

Scheme of pollutant production in animal building 